\title{
Post-transplant bendamustine reduces GvHD while preserving GvL in experimental haploidentical bone marrow transplantation
}

\author{
Jessica Stokes $^{1^{*}}$ \\ Emely A. Hoffman ${ }^{1 *}$ \\ Yi Zeng ${ }^{1,5}$ \\ Nicolas Larmonier ${ }^{1,2,5, \text {,* }}$ \\ Emmanuel Katsanis $\mathbf{s}^{1,2,3,4,5}$ \\ *JS and EH contributed equally to the manuscript. \\ Department of Pediatrics ${ }^{1}$, Immunobiology ${ }^{2}$, Medicine ${ }^{3}$, Pathology ${ }^{4}$, \\ and the University of Arizona Cancer Center ${ }^{5}$ \\ University of Arizona, Tucson, Arizona \\ ** Current address: CNRS UMR5164, University of Bordeaux, France
}

Corresponding author: Emmanuel Katsanis, M.D., Department of Pediatrics, 1501 N. Campbell Ave., PO Box 245073, Tucson, AZ 85724-5073; $\quad$ Tel.: (520) 6267053; katsanis@peds.arizona.edu. 


\section{ABSTRACT}

Advances in haploidentical bone marrow transplantation (h-BMT) have drastically broadened the treatment options for patients requiring BMT. The possibility of significantly reducing the complications resulting from graft-versus-host disease (GvHD) with the administration of post-transplant cyclophosphamide (PT-CY) has substantially improved the efficacy and applicability of T-replete h-BMT. However, higher frequency of disease recurrence remains a major challenge in h-BMT with $\mathrm{PT}-\mathrm{CY}$. There is a critical need to identify novel strategies to prevent GvHD while sparing graft versus leukemia (GvL) in h-BMT. To this end, we evaluated the impact of bendamustine (BEN), given post-transplant, on GvHD and GvL using clinically relevant murine h-BMT models. We provide results indicating that post-transplant bendamustine (PT-BEN) alleviates GvHD, significantly improving survival, while preserving engraftment and GvL effects. We further document that PT-BEN can mitigate GvHD even in the absence of Treg. Our results also indicate that PT-BEN is less myelosuppressive than PT-CY, significantly increasing the number and proportion of $\mathrm{CD} 11 \mathrm{~b}^{+} \mathrm{Gr}-1^{\text {hi }}$ cells, while decreasing lymphoid cells. In vitro we observed that BEN enhances the suppressive function of myeloidderived suppressor cells (MDSCs) while impairing the proliferation of $\mathrm{T}$ - and B-cells. These results advocate for the consideration of PT-BEN as a new therapeutic platform for clinical implementation in h-BMT.

Keywords: bone marrow transplantation, graft versus host disease, graft versus leukemia, bendamustine, cyclophosphamide 


\section{INTRODUCTION}

Allogeneic hematopoietic cell transplantation (HCT) is potentially curative for many patients with hematologic disorders and malignancies. However, the identification of suitable HLA-matched donors remains a challenge, particularly for patients of minority or mixed race(Gragert, et al 2014, Pidala, et al 2013, Switzer, et al 2013). Since every individual shares one HLA haplotype with each biological parent and with $50 \%$ of siblings, a familial haploidentical donor is immediately available in most cases, avoiding the delays associated with unrelated donor identification. Haploidentical HCT has therefore become a mainstream transplant option(Bacigalupo, et al 2015, Castagna, et al 2014, Fuchs 2015, Handgretinger 2014, Martelli, et al 2014, Martelli, et al 2015, McCurdy, et al 2015, Raiola, et al 2014).

Graft-versus-host disease (GvHD) represents a common complication in T-replete haploidentical-BMT (h-BMT), but is significantly reduced by the administration of cyclophosphamide post-transplant (PT-CY)(Brodsky, et al 2008). Graft engineering strategies are also being evaluated with the aim of reducing GvHD, including the depletion of $\mathrm{CD}^{+}$or TCR- $\alpha \beta^{+}$and $\mathrm{CD} 19^{+}$cells, concurrently enriching for $\mathrm{CD} 34^{+}$cells, TCR- $\mathrm{\gamma} \delta^{+}, \mathrm{NK}$ cells and T regulatory cells (Treg) (Di lanni, et al 2011a, Di lanni, et al 2011b, Dvorak, et al 2013, Federmann, et al 2012, Locatelli, et al 2013, Martelli, et al 2014). While some of these approaches appear promising, they are restricted to centers that have graft-engineering capabilities. T-cell-replete h-BMT with PT-CY has therefore emerged as a leading h-BMT approach as it circumvents the need to manipulate stem cell grafts and can be applied at any BMT center(Luznik and Fuchs 2010, Luznik, et al 2012). PT-CY, especially when implemented following reduced intensity conditioning (RIC), has been associated with relapse rates as high as 55\%(Munchel, et al 2011). This has prompted the consideration of myeloablative conditioning (MAC) regimens to reduce relapse rates, but at the cost of increasing GvHD and non-relapse mortality(Bacigalupo, et al 2015, Ciurea, et al 2015b, Solomon, et al 2015). 
In this context, we investigated the feasibility of using the bifunctional mechlorethamine derivative bendamustine (BEN), an active alkylator and purine analog, following $\mathrm{h}$ BMT(Hartmann and Zimmer 1972, Tageja and Nagi 2010). BEN has been used effectively against lymphomas(Corazzelli, et al 2013, Derenzini, et al 2014, Kahl, et al 2010, Rigacci, et al 2012, Robinson, et al 2008), chronic lymphocytic leukemia(Bergmann, et al 2005, Quinquenel, et al 2015) and, more recently, as conditioning for allogeneic HCT(Khouri, et al 2014). This agent has also been applied as pre-treatment for chimeric antigen receptor T-cell therapy of leukemias, as it induces a sustained lymphodepletion earlier than other agents(Kalos, et al 2011). However, bendamustine has not been studied as a post-transplant immunomodulating agent. Based on this information, we evaluated the potential of BEN to serve as an alternative to PT-CY in mitigating GvHD following h-BMT. Our results indicate that post-transplant bendamustine (PT-BEN) can control GvHD following MAC and RIC h-BMT. More importantly, GvL effects were significantly stronger in PT-BEN than PT-CY treated mice. These findings uncover a novel application for BEN and may have a major translational impact on the development of more effective clinical h-BMT approaches. 


\section{METHODS}

\section{Mice}

Age-matched 5-12 week-old female CAF1/J and NOD-scid IL2R ${ }^{\text {null }}$ mice were purchased from The Jackson Laboratory (Bar Harbor, Maine), CB6F1 from Charles Rivers Laboratories (Wilmington, MA) and BALB/C from the National Cancer Institute (Frederick, MD). Mice were housed in specific pathogen-free conditions and cared for according to the guidelines of the University of Arizona Institutional Animal Care and Use Committee (IACUC).

\section{Haploidentical bone marrow transplantation}

Recipient CAF1/J (H-2 $\left.{ }^{\mathrm{d} / a}\right)$ mice received 600 (RIC) or 1000 (MAC) cGy total body irradiation (TBI) on day -1 using a Cesium 137 irradiator. On day 0 , mice received $10^{7} \mathrm{CB} 6 \mathrm{~F} 1\left(\mathrm{H}-2^{\mathrm{d} / \mathrm{b}}\right)$ bone marrow (BM) cells with or without $3 \times 10^{7}$ spleen cells (SC) intravenously (i.v.). Moribund mice were euthanized following IACUC-approved procedures and survival was monitored. Mice were weighed every three to four days and percent of starting weight was calculated. Mice were also scored clinically on skin integrity, fur, posture and activity and cumulative GvHD scores were calculated(Cooke, et al 1996).

\section{Preparation of total T-cells, CD25- T-cells, and T-cell-depleted BM}

Total T-cells were isolated from naïve CB6F1 spleens by negative selection using mouse Pan T-Cell Isolation Kit II (Miltenyi Biotec, Auburn, CA) with a purity of $>97 \%$. CD25 $5^{+}$T-cells were depleted from this population using CD25 Microbead Kit (Miltenyi Biotec) resulting in preparations containing less than $0.4 \%$ remaining $\mathrm{CD}^{2} 5^{+} \mathrm{FoxP} 3^{+}$cells. T-cells were depleted

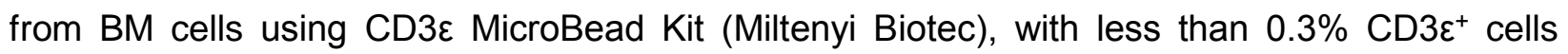
remaining. 


\section{Drug preparation and administration}

Cyclophosphamide (Sigma-Aldrich, St. Louis, MO) was reconstituted in sterile water (Hyclone, Logan, UT) and diluted in sterile saline (Fisher Scientific, Pittsburgh, PA) for intraperitoneal (i.p.) injection. Bendamustine was reconstituted in DMSO (Sigma-Aldrich) and diluted in sterile PBS (Hyclone) containing $0.2 \%$ carboxymethylcellulose and $0.25 \%$ polysorbate 80 (Sigma-Aldrich) for i.v. injection.

\section{A20 leukemia and imaging}

A20, a BALB/C B-cell lymphoblastic leukemia cell line, is radioresistant and has been used previously in murine BMT studies(Chen, et al 2006, Zeng, et al 2014) (American Type Culture Collection, Manassas, VA). A20 was cultured in RPMI 1640 with 10\% FBS, MEM, and sodium pyruvate (Cellgro, Manassas, VA) at $37^{\circ} \mathrm{C}$ and $5 \% \mathrm{CO}_{2}$. Luciferase-expressing A20 cells were generously provided by Dr. Xue-Zhong Yu, MD (Medical University of South Carolina). At various time points, A20-Luc bearing mice were given luciferin i.p. $0.15 \mathrm{mg} / \mathrm{g}$, anesthetized with isoflurane and imaged using a LagoX (Spectral Instruments Imaging, Tucson, AZ).

\section{Flow cytometry}

Cells were incubated with anti-mouse CD16/CD32 (BD Biosciences, San Jose, CA) for 15 minutes, then fluorochrome-conjugated antibodies for 30 minutes. Cells were fixed and permeabilized (Fixation/Permeabilization; eBioscience, San Diego, CA) before intracellular staining. Fluorescence data were collected with an LSRFortessa cell analyzer (BD Biosciences) and analyzed using FlowJo 2 (Tree Star, Ashland, OR). Antibodies used were anti-mouse CD4 APC (clone RM4-5), CD25 APC-eFluor780 (clone PC61.5), CD25 APC (clone PC61.5), Gr-1 FITC (clone RB6-8C5), CD11b eFluor450 (clone M1/70), FoxP3 AlexaFluor700 (clone FJK16s), FoxP3 APC (clone FJK-16s), H2kb PerCP-eFluor710 (clone AF6-88.5.5.3), CD8 PE-Cy7 
(clone 53-6.7) (eBioscience), B220 BV510 (clone RA3-6B2) (Biolegend), H2kk PE (clone 36-75), and CD3ع PE-CF594 (clone 145-2C11) (BD Biosciences).

\section{BM-derived MDSC generation, suppression assays and proliferation assays}

CB6F1 BM cells were cultured for 3 days at $0.5 \times 10^{6}$ cells $/ \mathrm{mL}$ with $10 \mathrm{ng} / \mathrm{mL}$ murine GM-CSF, IL-6 (Peprotech, Rocky Hill, NJ), human G-CSF (Amgen, Thousand Oaks, CA) and 0-100 $\mu \mathrm{M}$ BEN in DMEM with 10\% FBS (Hyclone)(Kurko, et al 2014). On day 3, cells were stained and analyzed by flow cytometry or co-cultured with stimulated CB6F1 T-cells to evaluate their suppressive function. T-cells were isolated from spleens using a Pan T-cell II Isolation Kit (MiltenyiBiotec), stained with CellTrace Violet ( $40 \mu \mathrm{M}, 5$ minutes; Life Technologies, Carlsbad, CA) and stimulated with CD3/CD28 beads (2 beads to 1 T-cell; Life Technologies). MDSCs were co-incubated with T-cells (1 MDSC to 2 T-cells) in RPMI with $10 \%$ FBS, MEM, sodium pyruvate and $55 \mu \mathrm{M} \beta$-mercaptoethanol (Sigma-Aldrich) for 3 days. Flow cytometry followed by Modfit (Verity Software House, Topsham, ME) analysis was used to determine the proliferation index $(\mathrm{PI})$ of the $\mathrm{T}$-cells. \% proliferation $=(\mathrm{PI}$ sample-PI unstimulated $\mathrm{T}$-cells $) /(\mathrm{PI}$ stimulated $\mathrm{T}$ cells-PI unstimulated T-cells) $\times 100$. Total T-cells for proliferation assays were prepared, stimulated, plated and analyzed as above. On day 3 of culture, cells were stained with anti-CD4 and CD8 and analyzed by flow cytometry. B-cells were isolated using a MiltenyiBiotec B-cell Isolation Kit, stained with CellTrace Violet and cultured for 5 days with $10 \mu \mathrm{g} / \mathrm{mL}$ LPS (SigmaAldrich). Cells were plated and analyzed as above.

\section{Statistics}


Kaplan-Meier curves were analyzed by log-rank test to determine survival percentages and differences between groups(Kaplan and Meier 1958, Peto and Peto 1972). Mann-Whitney tests were used to determine cell count, weight and GvHD score differences between groups.

\section{Study approval}

All animal studies were approved by the IACUC at The University of Arizona. 


\section{RESULTS}

\section{A fully haploidentical-BMT model is utilized as an experimental platform for GVHD.}

Most reported mouse haploidentical models use parent $\rightarrow \mathrm{F} 1$ combinations, which are limited by a lack of rejection of parent donor cells. To more closely mimic the environment encountered in human h-BMT, we established a more clinically relevant fully haploidentical

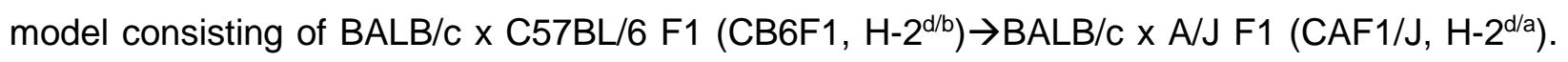
Besides offering the advantage of evaluating rejection and engraftment, transplantation of $\mathrm{CB} 6 \mathrm{~F} 1 \rightarrow \mathrm{CAF} 1 / \mathrm{J}$ recipients is associated with significantly more severe GvHD when compared to that of parent $\rightarrow$ F1 (Supplemental Figure 1). As T-cells constitute about $2 \%$ of murine bone marrow(Sykes 1990), recipients receiving only h-BMT did not develop lethal GvHD, irrespective of the intensity of conditioning. Co-injecting $3 \times 10^{7} \mathrm{~h}-\mathrm{SC}$ with $10^{7} \mathrm{~h}-\mathrm{BM}$ cells (h-BMT/SC) resulted in GvHD lethality (Figure 1). An increase in GvHD mortality relative to TBI intensity was evident in h-BMT/SC recipients, with mice receiving MAC dying of GVHD at a median time of 7 days versus 21 days for RIC (Figure 1).

PT-CY significantly prolonged survival with both conditioning regimens. However, $>95 \%$ of mice eventually died of GVHD following MAC and 25\% following RIC (Figure 1). Given these limitations of PT-CY, especially with MAC, we sought to evaluate novel agents that can be administered post-transplant to better control GvHD morbidity and mortality and focused our studies on PT-BEN.

\section{Donor cell engraftment is maintained with PT-BEN administration.}

Before evaluating the effects of BEN on GVHD, it was essential to determine the impact of this drug on donor cell engraftment. Chimerism was evaluated following MAC or RIC. Conditioned CAF1/J recipient mice received CB6F1 h-BM with or without h-SC. All mice receiving MAC achieved full donor chimerism following h-BMT. Mice retained this engraftment 
with the addition of both h-SC and PT-BEN (Figure 2). Mice receiving RIC followed by h-BMT had mixed chimerism on day +7 , with only half of the mice becoming fully chimeric by day +14 . The addition of $\mathrm{h}-\mathrm{SC}$ to the bone marrow infusion augmented donor chimerism to $60-95 \%$ by day +7 and $100 \%$ by day +14 , which remained stable when assessed on day +77 . Mice receiving PT-BEN exhibited $80-95 \%$ donor chimerism on day +7 , increasing to complete donor chimerism in all mice by day +14 (Figure 2). These results confirm that PT-BEN maintains donor cell engraftment.

\section{PT-BEN is as efficient as PT-CY at mitigating GvHD.}

Experiments were first undertaken to evaluate the most effective dose and timing of PTBEN. We found that a single dose of $30 \mathrm{mg} / \mathrm{kg}$ on day +3 was most effective at reducing GVHD (Supplemental Figure 2). Based on our determination of the maximum tolerated doses of BEN and $\mathrm{CY}$ in CAF1/J (Supplemental Figure 3), we chose a comparable CY dose of $150 \mathrm{mg} / \mathrm{kg}$, remaining within the range (66 to $200 \mathrm{mg} / \mathrm{kg}$ ) shown by Luznik and others to effectively mitigate GvHD(Ganguly, et al 2014, Ross, et al 2013). Our data confirmed that $150 \mathrm{mg} / \mathrm{kg}$ PT-CY on day +3 or $75 \mathrm{mg} / \mathrm{kg}$ on days +3 and +4 were equally effective at reducing GvHD (data not shown).

To compare the efficacy of PT-BEN to PT-CY, mice received MAC or RIC TBI, followed by h-BMT/SC and PT-BEN or PT-CY. Compared to animals receiving h-BMT/SC alone, survival was significantly improved or prolonged by both PT-BEN (31\% MAC and $88 \%$ RIC) and PT-CY (0\% MAC and 63\% RIC) with no significant difference between the treatment groups (Figure 3A). This indicates that PT-BEN is endowed with GvHD protective properties equivalent to those of PT-CY in our model. Mice receiving PT-BEN or PT-CY exhibited comparable weight loss and early GvHD scores (Figure 3B,C). However, signs of clinical GvHD progressively improved in PT-BEN treated mice, leading to GvHD scores significantly lower than those of PT- 
CY treated mice (Figure 3C). As expected, mice from all groups receiving MAC had more prominent weight loss and corresponding increases in GvHD scores when compared to mice receiving RIC (Figure 3B,C). Together, our data demonstrate that at these doses PT-BEN is as effective as PT-CY in reducing GVHD morbidity and mortality in both MAC and RIC murine hBMT settings.

To further investigate GVHD morbidity, animals receiving h-BMT or h-BMT/SC followed by PT-BEN or PT-CY were euthanized on days $+21,+35$, or +49 for histologic evaluation of colonic and hepatic GvHD. As the majority of mice receiving h-BMT/SC die prior to day +21 , we were not able to include them as untreated positive controls. Colons from mice receiving h-BMT without h-SC showed little evidence of GvHD early, with some colonic abnormalities at later time points, likely due to the presence of T-cells in the BM inoculum. In contrast, mice receiving $\mathrm{h}$ BMT/SC with PT-BEN or PT-CY demonstrated mild to moderate subacute multifocal to coalescing colitis with moderate crypt hyperplasia, mixed lymphocytic and neutrophilic infiltrates and, in some cases, mucosal ulceration consistent with GvHD. Histological colon GvHD scores(Burich, et al 2001) of mice receiving PT-BEN were comparable to those receiving PT-CY (Figure 4A,B). Similarly, mice receiving h-BMT alone showed no significant pathology in their livers, while those receiving h-BMT/SC with PT-BEN or PT-CY demonstrated similar degrees of mild multifocal chronic active cholangitis indicative of liver GvHD (Figure 4C).

The protective effects of PT-BEN against GvHD are not dependent on donor $C D 25^{+} T$ cells.

Additional experiments were performed to assess the role of donor Treg in PT-BENmediated protection from GvHD. Recipient mice received T-cell-depleted (TCD) h-BMT on day 0 with $6 \times 10^{6}$ purified splenic T-cells (total T) or CD25+ depleted T-cells (CD25 $\mathrm{T}$ ). The GvHD observed with total $\mathrm{T}$ was not severe enough to allow significant survival advantage with PT- 
BEN (data not shown). When CD25 ${ }^{+}$T-cells were eliminated from the haploidentical T-cell inoculum, GvHD lethality and morbidity significantly increased (Figure 5). Infusion of $6 \times 10^{6}$ CD25 T-cells on day 0 led to the death of all recipients, with most occurring before day +10 , substantiating the importance of $\mathrm{CD} 25^{+}$Treg in suppressing GvHD in this h-BMT model. Treatment of mice receiving $6 \times 10^{6} \mathrm{CD} 25^{-}$T-cells with PT-BEN significantly improved survival from 0 to $50 \%$ at +140 days. Moreover, these surviving mice regained their weight and showed minimal signs of GvHD at day +140 (Figure 5). These data clearly demonstrate that PT-BEN can suppress GvHD in the absence of donor Treg.

\section{PT-BEN is less myelosuppressive than PT-CY.}

To further explore the potential benefits of PT-BEN over PT-CY, mouse peripheral blood counts were analyzed serially post-transplant. PT-BEN was less myelosuppressive than PT-CY with a day +7 average white blood cell (WBC) count of $4.5 \times 10^{9} / \mathrm{L}$ compared to $0.32 \times 10^{9} / \mathrm{L}$ following MAC $(P<.001)$ and $5.7 \times 10^{9} / \mathrm{L}$ compared to $0.48 \times 10^{9} / \mathrm{L}$ following $\mathrm{RIC}(P<.00001)$ (Figure 6A). PT-BEN maintained a higher WBC count than PT-CY through day +12 and by day +14 counts had similarly recovered in both groups (Supplemental Figure 4A). PT-BEN was relatively more lymphodepleting than myelosuppressive when compared to PT-CY with a myeloid to lymphoid ratio of 14.6 compared to 0.48 following MAC and 17.6 compared to 0.55 following RIC on day +7 (Figure 6A). When analyzed daily, PT-BEN treated mice had a higher myeloid to lymphoid ratio through day +13 . By day +14 , the ratios were comparable (Supplemental Figure 4B). PT-BEN treated mice, in contrast to PT-CY treated mice, never became neutropenic (defined as $<100$ neutrophils $\times 10^{9} / \mathrm{L}$ blood)(von Vietinghoff and Ley 2008 , Zuluaga, et al 2006) when analyzed days +4 to 14 (Supplemental Figure 4C). When compared to PT-CY, PT-BEN treated mice exhibited higher hemoglobin, platelet and red blood cell counts 
through day +14 following MAC (Supplemental Figure $5 \mathrm{~A}$ ). There was no clear pattern following RIC (Supplemental Figure 5B).

\section{PT-BEN increases MDSC frequency.}

Flow cytometric analysis was used to further examine peripheral blood cell populations. Treg, phenotypically defined as $\mathrm{CD} 4^{+} \mathrm{CD} 25^{+} \mathrm{FoxP} 3^{+}$cells, and myeloid derived suppressor cells (MDSCs), defined as suppressive $C D 11 \mathrm{~b}^{+} \mathrm{Gr}-1^{+}$cells, are two main immune cell populations widely described for their immunosuppressive properties, which play an essential role in the control of GvHD(Colonna, et al 2011, Highfill, et al 2010). As the lymphoid counts were extremely low on day +7 , it was not feasible to perform an analysis of potential differences in the percent of Treg, T-cells or B-cells between the PT-BEN and PT-CY groups. FoxP3 ${ }^{+}$cells comprised $0.1-0.2 \%$ of peripheral blood cells in PT-BEN and PT-CY groups following MAC or RIC on day +14 , with a higher absolute number in PT-CY treated mice. On days +35 and +77 , there was a two-fold increase in FoxP3 ${ }^{+}$cells in the peripheral blood of PT-CY relative to PTBEN treated groups (Figure 6B). The absolute lymphoid subset numbers between PT-BEN and PT-CY were not significantly or consistently different, except $\mathrm{CD} 4^{+}$cells were higher with PT-CY following MAC (Figure $6 C, D$ ). In contrast, the number of $C D 11 b^{+} G r-1^{\text {hi }}$ cells was significantly higher in recipients of PT-BEN when compared to PT-CY on day +7 following MAC and days +7 and +14 following RIC (Figure 6E). Importantly, Gr-1 ${ }^{\text {hi }}$ cells isolated from the blood and spleen of PT-BEN treated mice strongly suppressed T-cell proliferation (Supplemental Figure 6), confirming their identity as MDSCs.

BEN enhances MDSC suppressive function and impairs T- and B-cell proliferation in vitro. 
PT-BEN is lymphodepleting, relatively spares the myeloid compartment and significantly increases MDSCs. We therefore further investigated the differential effects of BEN on these subsets in vitro. MDSCs were generated from naïve BM in the presence of increasing concentrations of BEN. After 3 days in culture $>90 \%$ of cells were CD11 $\mathrm{b}^{+} \mathrm{Gr}-1^{+}$(Supplemental Figure 7), with no significant differences between groups. MDSCs generated with higher concentrations of BEN were significantly more suppressive than those generated with lower concentrations (Figure 7A).

Importantly, T-cells from naïve mice stimulated by anti-TCR/CD28 antibodies in the presence of BEN concentrations identical to those used in MDSC generation were less proliferative than those cultured in the absence of $\mathrm{BEN}$. Both $\mathrm{CD} 4^{+}$and $\mathrm{CD} 8^{+} \mathrm{T}$-cell proliferation were reduced by BEN with more significant suppression of $\mathrm{CD} 4^{+}$proliferation. Suppression of proliferation could not be attributed to loss of T-cell viability (Figure 7B). When B-cells were cultured with the same concentrations, they became even less proliferative with a significant decrease in viability at $100 \mu \mathrm{M}$ (Figure 7C).

\section{PT-BEN mitigates GvHD but maintains GvL in the A20 leukemia model.}

As BEN significantly suppresses GvHD, it was essential to determine its effects on GvL, specifically assessing whether anti-tumoral activity was maintained with PT-BEN treatment. First, we determined the possible direct effect of BEN on A20 in vivo. This was an important step to discriminate between the possible immunomodulatory effects of BEN and its direct anticancer activity. BEN $30 \mathrm{mg} / \mathrm{kg} /$ day was administered 5 and 6 days after i.v. A20 inoculation of immunocompetent BALB/C and immunodeficient NOD-scid IL2Ry ${ }^{\text {null }}$ mice (lacking mature Tcells, B-cells and functional NK cells). In immunocompetent tumor-bearing BALB/c mice, BEN had a minimal anti-A20 effect, increasing the median survival by only four days compared to no treatment (Figure 8A). Similarly, in NOD-scid IL2R ${ }^{\text {vnull }}$ mice with A20 leukemia, BEN only 
prolonged survival by three days (Figure 8B). By comparison, $\mathrm{CY}$ demonstrated a more potent direct anti-tumor activity against A20 (CY vs BEN $P<.002$ in BALB/C and $P<.006$ in NOD-scid IL2R $\left.{ }^{\text {null}}\right)$. The total dose of BEN $60 \mathrm{mg} / \mathrm{kg}$ given to these mice represents $85 \%$ of the MTD, compared to only $34 \%$ of the MTD for CY $(150 \mathrm{mg} / \mathrm{kg})$. This result confirms that A20 are more sensitive to $\mathrm{CY}$ than BEN. Therefore, PT-BEN could not be compared to PT-CY when tumor was given before transplant, as it would be impossible to distinguish the GvL effects from the direct anti-tumor activity.

Experiments were undertaken to determine the impact of PT-BEN on the survival of leukemia-bearing mice undergoing h-BMT. Given that anti-A20 leukemia effects of BEN are minimal, an increase in survival of leukemia-bearing mice would be attributable primarily to GvL activity. A20 tumor-bearing mice received RIC and h-BMT or h-BMT/SC + PT-BEN. PT-BEN significantly increased survival from leukemia compared to untreated mice (Figure 8C).

The preservation of significant GVL activity by PT-BEN was confirmed using luciferaseexpressing A20 injected i.v. one day after chemotherapy (thereby eliminating any possible direct anti-leukemia activity). All mice receiving h-BMT/SC died of GvHD without evidence of leukemia. The survival of h-BMT/SC mice treated with PT-BEN was significantly better than that of animals treated with PT-CY. Importantly, the survival of mice receiving h-BMT/SC + PT-CY was not significantly different than that of mice receiving h-BMT alone, which did not develop clinically significant GvHD or GVL (Figure 8D). Similarly, in another experiment, mice received RIC, TCD-h-BMT or h-BMT/SC with and without PT-BEN or CY on day +3 and A20-Luc cells i.v. on day +4. Mice were imaged serially. PT-BEN treated mice demonstrated no evidence of A20Luc leukemia as late as day +70 , while those receiving PT-CY showed onset of leukemia as early as day +22 with all mice dying of leukemia by day +48 . All untreated $h-B M T / S C$ mice died of GvHD by day +45 . This is shown in the images and confirmed by quantification of the photons/second (Figure 9A,B). These results indicate that although PT-CY efficiently reduces mortality related to GvHD, it concomitantly reduces GvL activity in this model, while PT-BEN 
does not. The effectiveness of PT-BEN at preserving GVL was confirmed in the MAC and RIC models, using two different doses of SC to induce GvHD with different degrees of severity (Supplemental Figure 8). This highlights the potential therapeutic benefit of BEN over CY in this setting. 


\section{DISCUSSION}

Recently, the application of haploidentical HCT has significantly expanded. The integration of PT-CY has emerged as the most widely applied h-BMT approach, partly because of its simplicity. However, high relapse rates observed in the setting of RIC have dampened enthusiasm for this strategy, particularly for patients with acute leukemias(Ciurea, et al 2015a). In an effort to identify an alternative agent that can readily be used to overcome the deleterious impact of GVHD while maintaining GvL, we evaluated PT-BEN. While BEN is noted for potent immunosuppressive and lymphodepleting activities, its ability to prevent or suppress GvHD when given post-transplant has not been published previously in human or murine BMT models. BEN has, however, been incorporated as a conditioning agent prior to matched allogeneic BMT and donor lymphocyte infusion(Khouri, et al 2014, Sala, et al 2014).

Using clinically relevant fully haploidentical F1 $\rightarrow$ F1 models, we provide the first evidence that PT-BEN represents an efficient and feasible alternative to PT-CY. Mice receiving $h$ BMT/SC followed by PT-BEN developed sustained donor chimerism. PT-BEN used at a comparable dose, based on determined MTDs in recipient CAF1/J mice, protected against GvHD as effectively as PT-CY. Additionally, we determined that PT-BEN significantly improved the survival of leukemia-bearing mice receiving RIC and h-BMT/SC compared those receiving h-BMT alone. This anti-leukemic effect was mediated primarily through GVL as even a two-fold increase in the dose of BEN demonstrated minimal direct cytotoxic activity against A20 leukemia in non-transplanted BALB/c and NOD-scid IL2R $\mathbf{y}^{\text {null }}$ mice. Furthermore, when A20-Luc was given after chemotherapy to avoid the inequity of direct cytotoxic effects of BEN and CY, mice receiving PT-BEN demonstrated a significant delay in leukemia development compared to mice receiving PT-CY, where both GVHD and GVL were significantly suppressed. Taken together, these data demonstrate that PT-BEN effectively controls GvHD and has significant advantages over PT-CY in preserving GvL activity. 
Treg play an essential role in the maintenance of immunologic self-tolerance(Sakaguchi, et al 2008). Extensive evidence has shown the balance between effector T-cells and Treg is critical for the control of GVHD(Ermann, et al 2005, Nguyen, et al 2008, Taylor, et al 2004, Zeiser, et al 2008). Consistent with previous studies in various allogeneic mismatched murine BMT models, our results indicate that in RIC h-BMT, removal of CD25+ T-cells (which include $\mathrm{CD}^{+} \mathrm{CD}_{25}{ }^{+} \mathrm{FoxP}^{+}$Treg) from the T-cell infusion significantly increases GvHD lethality(Zeiser, et al 2006). It is believed that the predominant effect of PT-CY depletes alloreactive T-cells early post-HCT(Luznik, et al 2002, Luznik, et al 2001, Luznik, et al 2008). However, Luznik et al. recently reported that $\mathrm{CD} 4^{+} \mathrm{FoxP}^{+}$Treg were essential for GvHD protection by PT-CY in MHCmatched and MHC-mismatched models, with T-cell allografts containing both CD4+ and CD8+ cells(Ganguly, et al 2014). PT-BEN is also an effective lymphodepleting agent, likely partially exerting its effects by eliminating alloreactive T-cells. In our haploidentical model, PT-BEN significantly increased survival even when allografts were depleted of Treg (7-9\% of the total Tcell population). As reported by Luznik et al in other models(Ganguly, et al 2014), we observed that PT-CY led to an increase in Tregs at later time points, while PT-BEN did not. The mechanism of action of PT-BEN therefore appears to differ from that of PT-CY.

As PT-BEN is more lymphodepleting (including Treg) than myelosuppressive, relative to PT-CY, and results in higher numbers of suppressive $C D 11 b^{+} G r-1^{\text {hi }}$ cells in the blood, it is conceivable that MDSCs contribute to its mechanism of GvHD suppression. Additionally, the presence of BEN during MDSC generation in vitro increased their suppressive activity. The same concentrations of BEN markedly decreased the proliferation of $\mathrm{CD}^{+}$and $\mathrm{CD}^{+}{ }^{+}$-cells and B-cells in vitro. These data suggest that BEN improves MDSC function while reducing Tand B-cell function. It is noteworthy that $\mathrm{CD} 4^{+} \mathrm{T}$-cells were more affected by BEN than $\mathrm{CD} 8^{+} \mathrm{T}$ cells, suggesting the relative sparing of $\mathrm{CD}^{+} \mathrm{T}$-cells could contribute to GVL activity. In addition, BEN exhibited more pronounced effects on the proliferation of B-cells than T-cells. B-cells play a pivotal role in the development of chronic GvHD(Schultz, et al 1995, Srinivasan, et al 2012, 
Young, et al 2012). It is plausible that the pronounced, long-lasting depletion of B-cells by BEN may contribute to its effective long-term control of GVHD in our model. The role of PT-BEN on the interplay of these and other immune cells related to GvHD and GvL requires further elucidation.

In summary, we have documented that PT-BEN is an effective agent in suppressing GvHD while maintaining GvL in clinically relevant RIC and MAC experimental haploidentical BMT models. With PT-BEN, preservation of GVL was in striking contrast to the abrogation seen with PT-CY. Additionally, BEN is less myelosuppressive than $\mathrm{CY}$ and may decrease the duration of severe neutropenia, significantly reducing the risk of infections(Khouri, et al 2014). BEN used alongside fludarabine and rituximab as conditioning in allo-transplantation was welltolerated and effective(Khouri, et al 2014). Its safety profile was recently confirmed in a randomized trial of $\mathrm{BEN}$ plus rituximab versus $\mathrm{R}-\mathrm{CHOP}$ with fewer hematologic and other toxicities and infections(Becker, et al 2015). BEN has not been noted to have the significant cardiac and pulmonary toxicity(Becker, et al 2015) or augmentation of TBI-induced lung damage(Sampath, et al 2005, Shi-Xia, et al 2010) that is often seen following CY conditioning(Ayash, et al 1992, Braverman, et al 1991, Cazin, et al 1986, Malik, et al 1996, Mills and Roberts 1979). BEN, however, may be associated with hyperbilirubinemia, rash and diarrhea, which may be confused with onset of GvHD, and its safety post-h-BMT remains to be determined in humans(Becker, et al 2015). Regardless of these potential limitations, PT-BEN deserves further investigation as a potentially effective post-transplant approach following Treplete h-BMT. Given that PT-CY on day +3 and 4 is the standard of care in T-replete h-BMT, a proposed phase I trial at our institution will gradually de-escalate PT-CY while escalating BEN to a dose of $100 \mathrm{mg} / \mathrm{m}^{2}$, starting with the day +4 dose. 


\section{AUTHOR CONTRIBUTIONS}

J.S. and E.H. designed and performed experiments, analyzed and reviewed data, and co-wrote the manuscript. Y.Z. and N.L. contributed to experimental design, data interpretation and discussion and revised the manuscript. E.K. designed the project, supervised and advised on the implementation and conduction of experiments, reviewed and interpreted data, and wrote the manuscript.

The authors have declared that no conflict of interest exists. 


\section{ACKNOWLEDGEMENTS}

The authors wish to thank Sofie De Prins, Vesna Pulko, Min Hahn, and Shivali Justa for technical assistance, Vanessa Frisinger for administrative assistance, and Dr. David Besselsen for sharing his expertise in histological analysis. We would also like to thank Paula Campbell and the University of Arizona's Cytometry Core Facility for the use of their analytical software and the University of Arizona's Imaging Lab for their services. This work was supported by the National Institutes of Health grant R01 CA104926 (E.K.), Hyundai Hope on Wheels, Tee up for Tots, Angel Charity for Children and PANDA. 


\section{References:}

Ayash, L.J., Wright, J.E., Tretyakov, O., Gonin, R., Elias, A., Wheeler, C., Eder, J.P., Rosowsky, A., Antman, K. \& Frei, E., 3rd (1992) Cyclophosphamide pharmacokinetics: correlation with cardiac toxicity and tumor response. J Clin Oncol, 10, 995-1000.

Bacigalupo, A., Dominietto, A., Ghiso, A., Di Grazia, C., Lamparelli, T., Gualandi, F., Bregante, S., Van Lint, M.T., Geroldi, S., Luchetti, S., Grasso, R., Pozzi, S., Colombo, N., Tedone, E., Varaldo, R. \& Raiola, A.M. (2015) Unmanipulated haploidentical bone marrow transplantation and post-transplant cyclophosphamide for hematologic malignanices following a myeloablative conditioning: an update. Bone Marrow Transplant, $\mathbf{5 0}$ Suppl 2, S37-39.

Becker, M., Tschechne, B., Reeb, M., Schwinger, U., Bruch, H.R., Frank, M. \& Strassl, L. (2015) Bendamustine as first-line treatment in patients with advanced indolent non-Hodgkin lymphoma and mantle cell lymphoma in German routine clinical practice. Ann Hematol, 94, 1553-1558.

Bergmann, M.A., Goebeler, M.E., Herold, M., Emmerich, B., Wilhelm, M., Ruelfs, C., Boening, L., Hallek, M.J. \& German, C.L.L.S.G. (2005) Efficacy of bendamustine in patients with relapsed or refractory chronic lymphocytic leukemia: results of a phase I/II study of the German CLL Study Group. Haematologica, 90, 1357-1364.

Braverman, A.C., Antin, J.H., Plappert, M.T., Cook, E.F. \& Lee, R.T. (1991) Cyclophosphamide cardiotoxicity in bone marrow transplantation: a prospective evaluation of new dosing regimens. J Clin Oncol, 9, 1215-1223.

Brodsky, R.A., Luznik, L., Bolanos-Meade, J., Leffell, M.S., Jones, R.J. \& Fuchs, E.J. (2008) Reduced intensity HLA-haploidentical BMT with post transplantation cyclophosphamide in nonmalignant hematologic diseases. Bone Marrow Transplant, 42, 523-527.

Burich, A., Hershberg, R., Waggie, K., Zeng, W., Brabb, T., Westrich, G., Viney, J.L. \& MaggioPrice, L. (2001) Helicobacter-induced inflammatory bowel disease in IL-10- and T celldeficient mice. Am J Physiol Gastrointest Liver Physiol, 281, G764-778.

Castagna, L., Bramanti, S., Furst, S., Giordano, L., Crocchiolo, R., Sarina, B., Mauro, E., Morabito, L., Bouabdallah, R., Coso, D., Balzarotti, M., Broussais, F., El-Cheikh, J., Stella, C.C., Brusamolino, E., Blaise, D. \& Santoro, A. (2014) Nonmyeloablative conditioning, unmanipulated haploidentical SCT and post-infusion CY for advanced lymphomas. Bone Marrow Transplant, 49, 1475-1480.

Cazin, B., Gorin, N.C., Laporte, J.P., Gallet, B., Douay, L., Lopez, M., Najman, A. \& Duhamel, G. (1986) Cardiac complications after bone marrow transplantation. A report on a series of 63 consecutive transplantations. Cancer, 57, 2061-2069.

Chen, X., Zeng, Y., Li, G., Larmonier, N., Graner, M.W. \& Katsanis, E. (2006) Peritransplantation vaccination with chaperone-rich cell lysate induces antileukemia immunity. Biol Blood Marrow Transplant, 12, 275-283.

Ciurea, S.O., Zhang, M.J., Bacigalupo, A.A., Bashey, A., Appelbaum, F.R., Aljitawi, O.S., Armand, P., Antin, J.H., Chen, J., Devine, S.M., Fowler, D.H., Luznik, L., Nakamura, R., O'Donnell, P.V., Perales, M.A., Pingali, S.R., Porter, D.L., Riches, M.R., Ringden, O.T., Rocha, V., Vij, R., Weisdorf, D.J., Champlin, R.E., Horowitz, M.M., Fuchs, E.J. \& Eapen, M. (2015a) Haploidentical transplant with post-transplant cyclophosphamide versus matched unrelated donor transplant for acute myeloid leukemia. Blood, Prepublished online June 30, 2015.

Ciurea, S.O., Zhang, M.J., Bacigalupo, A.A., Bashey, A., Appelbaum, F.R., Aljitawi, O.S., Armand, P., Antin, J.H., Chen, J., Devine, S.M., Fowler, D.H., Luznik, L., Nakamura, R., O'Donnell, P.V., Perales, M.A., Pingali, S.R., Porter, D.L., Riches, M.R., Ringden, O.T., Rocha, V., Vij, R., Weisdorf, D.J., Champlin, R.E., Horowitz, M.M., Fuchs, E.J. \& Eapen, 
M. (2015b) Haploidentical transplant with posttransplant cyclophosphamide vs matched unrelated donor transplant for acute myeloid leukemia. Blood, 126, 1033-1040.

Colonna, L., Sega, E.I. \& Negrin, R.S. (2011) Natural and expanded CD4(+)CD25(+) regulatory T cells in bone marrow transplantation. Biol Blood Marrow Transplant, 17, S58-62.

Cooke, K.R., Kobzik, L., Martin, T.R., Brewer, J., Delmonte, J., Jr., Crawford, J.M. \& Ferrara, J.L. (1996) An experimental model of idiopathic pneumonia syndrome after bone marrow transplantation: I. The roles of minor $\mathrm{H}$ antigens and endotoxin. Blood, 88, 3230-3239.

Corazzelli, G., Angrilli, F., D'Arco, A., Ferrara, F., Musto, P., Guarini, A., Cox, M.C., Stelitano, C., Storti, S., Iannitto, E., Falorio, S., Califano, C., Amore, A., Arcamone, M., De Filippi, R. \& Pinto, A. (2013) Efficacy and safety of bendamustine for the treatment of patients with recurring Hodgkin lymphoma. Br J Haematol, 160, 207-215.

Derenzini, E., Zinzani, P.L. \& Cheson, B.D. (2014) Bendamustine: role and evidence in lymphoma therapy, an overview. Leuk Lymphoma, 55, 1471-1478.

Di Ianni, M., Falzetti, F., Carotti, A., Terenzi, A., Castellino, F., Bonifacio, E., Del Papa, B., Zei, T., Ostini, R.I., Cecchini, D., Aloisi, T., Perruccio, K., Ruggeri, L., Balucani, C., Pierini, A., Sportoletti, P., Aristei, C., Falini, B., Reisner, Y., Velardi, A., Aversa, F. \& Martelli, M.F. (2011a) Tregs prevent GVHD and promote immune reconstitution in HLA-haploidentical transplantation. Blood, 117, 3921-3928.

Di Ianni, M., Falzetti, F., Carotti, A., Terenzi, A., Del Papa, B., Perruccio, K., Ruggeri, L., Sportoletti, P., Rosati, E., Marconi, P., Falini, B., Reisner, Y., Velardi, A., Aversa, F. \& Martelli, M.F. (2011b) Immunoselection and clinical use of $T$ regulatory cells in HLAhaploidentical stem cell transplantation. Best Pract Res Clin Haematol, 24, 459-466.

Dvorak, C.C., Gilman, A.L., Horn, B., Oon, C.Y., Dunn, E.A., Baxter-Lowe, L.A. \& Cowan, M.J. (2013) Haploidentical related-donor hematopoietic cell transplantation in children using megadoses of CliniMACs-selected CD34(+) cells and a fixed CD3(+) dose. Bone Marrow Transplant, 48, 508-513.

Ermann, J., Hoffmann, P., Edinger, M., Dutt, S., Blankenberg, F.G., Higgins, J.P., Negrin, R.S., Fathman, C.G. \& Strober, S. (2005) Only the CD62L+ subpopulation of CD4+CD25+ regulatory T cells protects from lethal acute GVHD. Blood, 105, 2220-2226.

Federmann, B., Bornhauser, M., Meisner, C., Kordelas, L., Beelen, D.W., Stuhler, G., Stelljes, M., Schwerdtfeger, R., Christopeit, M., Behre, G., Faul, C., Vogel, W., Schumm, M., Handgretinger, R., Kanz, L. \& Bethge, W.A. (2012) Haploidentical allogeneic hematopoietic cell transplantation in adults using CD3/CD19 depletion and reduced intensity conditioning: a phase II study. Haematologica, 97, 1523-1531.

Fuchs, E.J. (2015) HLA-haploidentical blood or marrow transplantation with high-dose, posttransplantation cyclophosphamide. Bone Marrow Transplant, 50 Suppl 2, S31-36.

Ganguly, S., Ross, D.B., Panoskaltsis-Mortari, A., Kanakry, C.G., Blazar, B.R., Levy, R.B. \& Luznik, L. (2014) Donor CD4+ Foxp3+ regulatory $T$ cells are necessary for posttransplantation cyclophosphamide-mediated protection against GVHD in mice. Blood, 124, 2131-2141.

Gragert, L., Eapen, M., Williams, E., Freeman, J., Spellman, S., Baitty, R., Hartzman, R., Rizzo, J.D., Horowitz, M., Confer, D. \& Maiers, M. (2014) HLA match likelihoods for hematopoietic stem-cell grafts in the U.S. registry. N Engl J Med, 371, 339-348.

Handgretinger, R. (2014) Haploidentical transplantation: the search for the best donor. Blood, 124, 827-828.

Hartmann, M. \& Zimmer, C. (1972) Investigation of cross-link formation in DNA by the alkylating cytostatic IMET 3106, 3393 and 3943. Biochim Biophys Acta, 287, 386-389.

Highfill, S.L., Rodriguez, P.C., Zhou, Q., Goetz, C.A., Koehn, B.H., Veenstra, R., Taylor, P.A., Panoskaltsis-Mortari, A., Serody, J.S., Munn, D.H., Tolar, J., Ochoa, A.C. \& Blazar, B.R. (2010) Bone marrow myeloid-derived suppressor cells (MDSCs) inhibit graft-versus-host 
disease (GVHD) via an arginase-1-dependent mechanism that is up-regulated by interleukin-13. Blood, 116, 5738-5747.

Kahl, B.S., Bartlett, N.L., Leonard, J.P., Chen, L., Ganjoo, K., Williams, M.E., Czuczman, M.S., Robinson, K.S., Joyce, R., van der Jagt, R.H. \& Cheson, B.D. (2010) Bendamustine is effective therapy in patients with rituximab-refractory, indolent B-cell non-Hodgkin lymphoma: results from a Multicenter Study. Cancer, 116, 106-114.

Kalos, M., Levine, B.L., Porter, D.L., Katz, S., Grupp, S.A., Bagg, A. \& June, C.H. (2011) T cells with chimeric antigen receptors have potent antitumor effects and can establish memory in patients with advanced leukemia. Sci Transl Med, 3, 95ra73.

Kaplan, E.L. \& Meier, P. (1958) Nonparametric-Estimation from Incomplete Observations. Journal of the American Statistical Association, 53, 457-481.

Khouri, I.F., Wei, W., Korbling, M., Turturro, F., Ahmed, S., Alousi, A., Anderlini, P., Ciurea, S., Jabbour, E., Oran, B., Popat, U.R., Rondon, G., Bassett, R.L., Jr. \& Gulbis, A. (2014) BFR (bendamustine, fludarabine, and rituximab) allogeneic conditioning for chronic lymphocytic leukemia/lymphoma: reduced myelosuppression and GVHD. Blood, 124, 2306-2312.

Kurko, J., Vida, A., Ocsko, T., Tryniszewska, B., Rauch, T.A., Glant, T.T., Szekanecz, Z. \& Mikecz, K. (2014) Suppression of proteoglycan-induced autoimmune arthritis by myeloid-derived suppressor cells generated in vitro from murine bone marrow. PLoS One, 9, e111815.

Locatelli, F., Bauquet, A., Palumbo, G., Moretta, F. \& Bertaina, A. (2013) Negative depletion of alpha/beta+ T cells and of CD19+ B lymphocytes: a novel frontier to optimize the effect of innate immunity in HLA-mismatched hematopoietic stem cell transplantation. Immunol Lett, 155, 21-23.

Luznik, L., Engstrom, L.W., lannone, R. \& Fuchs, E.J. (2002) Posttransplantation cyclophosphamide facilitates engraftment of major histocompatibility complex-identical allogeneic marrow in mice conditioned with low-dose total body irradiation. Biol Blood Marrow Transplant, 8, 131-138.

Luznik, L. \& Fuchs, E.J. (2010) High-dose, post-transplantation cyclophosphamide to promote graft-host tolerance after allogeneic hematopoietic stem cell transplantation. Immunol Res, 47, 65-77.

Luznik, L., Jalla, S., Engstrom, L.W., Iannone, R. \& Fuchs, E.J. (2001) Durable engraftment of major histocompatibility complex-incompatible cells after nonmyeloablative conditioning with fludarabine, low-dose total body irradiation, and posttransplantation cyclophosphamide. Blood, 98, 3456-3464.

Luznik, L., O'Donnell, P.V. \& Fuchs, E.J. (2012) Post-transplantation cyclophosphamide for tolerance induction in HLA-haploidentical bone marrow transplantation. Semin Oncol, 39, 683-693.

Luznik, L., O'Donnell, P.V., Symons, H.J., Chen, A.R., Leffell, M.S., Zahurak, M., Gooley, T.A., Piantadosi, S., Kaup, M., Ambinder, R.F., Huff, C.A., Matsui, W., Bolanos-Meade, J., Borrello, I., Powell, J.D., Harrington, E., Warnock, S., Flowers, M., Brodsky, R.A., Sandmaier, B.M., Storb, R.F., Jones, R.J. \& Fuchs, E.J. (2008) HLA-haploidentical bone marrow transplantation for hematologic malignancies using nonmyeloablative conditioning and high-dose, posttransplantation cyclophosphamide. Biol Blood Marrow Transplant, 14, 641-650.

Malik, S.W., Myers, J.L., DeRemee, R.A. \& Specks, U. (1996) Lung toxicity associated with cyclophosphamide use. Two distinct patterns. Am J Respir Crit Care Med, 154, 18511856.

Martelli, M.F., Di Ianni, M., Ruggeri, L., Pierini, A., Falzetti, F., Carotti, A., Terenzi, A., Reisner, Y., Aversa, F., Falini, B. \& Velardi, A. (2014) "Designed" grafts for HLA-haploidentical stem cell transplantation. Blood, 123, 967-973. 
Martelli, M.F., Ianni, M.D., Ruggeri, L., Falzetti, F., Carotti, A., Reisner, Y. \& Velardi, A. (2015) Next generation HLA-haploidentical HSCT. Bone Marrow Transplant, 50 Suppl 2, S6366.

McCurdy, S.R., Kanakry, J.A., Showel, M.M., Tsai, H.L., Bolanos-Meade, J., Rosner, G.L., Kanakry, C.G., Perica, K., Symons, H.J., Brodsky, R.A., Gladstone, D.E., Huff, C.A., Pratz, K.W., Prince, G.T., Dezern, A.E., Gojo, I., Matsui, W.H., Borrello, I., McDevitt, M.A., Swinnen, L.J., Smith, B.D., Levis, M.J., Ambinder, R.F., Luznik, L., Jones, R.J., Fuchs, E.J. \& Kasamon, Y.L. (2015) Risk-stratified outcomes of nonmyeloablative HLAhaploidentical BMT with high-dose posttransplantation cyclophosphamide. Blood, 125, 3024-3031.

Mills, B.A. \& Roberts, R.W. (1979) Cyclophosphamide-induced cardiomyopathy: a report of two cases and review of the English literature. Cancer, 43, 2223-2226.

Munchel, A.T., Kasamon, Y.L. \& Fuchs, E.J. (2011) Treatment of hematological malignancies with nonmyeloablative, HLA-haploidentical bone marrow transplantation and high dose, post-transplantation cyclophosphamide. Best Pract Res Clin Haematol, 24, 359-368.

Nguyen, V.H., Shashidhar, S., Chang, D.S., Ho, L., Kambham, N., Bachmann, M., Brown, J.M. \& Negrin, R.S. (2008) The impact of regulatory T cells on T-cell immunity following hematopoietic cell transplantation. Blood, 111, 945-953.

Peto, R. \& Peto, J. (1972) Asymptotically Efficient Rank Invariant Test Procedures. Journal of the Royal Statistical Society Series a-General, 135, 185-\&.

Pidala, J., Kim, J., Schell, M., Lee, S.J., Hillgruber, R., Nye, V., Ayala, E., Alsina, M., Betts, B., Bookout, R., Fernandez, H.F., Field, T., Locke, F.L., Nishihori, T., Ochoa, J.L., Perez, L., Perkins, J., Shapiro, J., Tate, C., Tomblyn, M. \& Anasetti, C. (2013) Race/ethnicity affects the probability of finding an HLA-A, -B, -C and -DRB1 allele-matched unrelated donor and likelihood of subsequent transplant utilization. Bone Marrow Transplant, 48, 346-350.

Quinquenel, A., Willekens, C., Dupuis, J., Royer, B., Ysebaert, L., Guibert, S., Michallet, A.S., Feugier, P., Guieze, R., Levy, V. \& Delmer, A. (2015) Bendamustine and rituximab combination in the management of chronic lymphocytic leukemia-associated autoimmune hemolytic anemia: A multicentric retrospective study of the French CLL intergroup (GCFLLC/MW and GOELAMS). Am J Hematol, 90, 204-207.

Raiola, A.M., Dominietto, A., di Grazia, C., Lamparelli, T., Gualandi, F., Ibatici, A., Bregante, S., Van Lint, M.T., Varaldo, R., Ghiso, A., Gobbi, M., Carella, A.M., Signori, A., Galaverna, F. \& Bacigalupo, A. (2014) Unmanipulated haploidentical transplants compared with other alternative donors and matched sibling grafts. Biol Blood Marrow Transplant, 20, 1573-1579.

Rigacci, L., Puccini, B., Cortelazzo, S., Gaidano, G., Piccin, A., D'Arco, A., Freilone, R., Storti, S., Orciuolo, E., Zinzani, P.L., Zaja, F., Bongarzoni, V., Balzarotti, M., Rota-Scalabrini, D., Patti, C., Gobbi, M., Carpaneto, A., Liberati, A.M., Bosi, A. \& Iannitto, E. (2012) Bendamustine with or without rituximab for the treatment of heavily pretreated nonHodgkin's lymphoma patients: A multicenter retrospective study on behalf of the Italian Lymphoma Foundation (FIL). Ann Hematol, 91, 1013-1022.

Robinson, K.S., Williams, M.E., van der Jagt, R.H., Cohen, P., Herst, J.A., Tulpule, A., Schwartzberg, L.S., Lemieux, B. \& Cheson, B.D. (2008) Phase II multicenter study of bendamustine plus rituximab in patients with relapsed indolent B-cell and mantle cell non-Hodgkin's lymphoma. J Clin Oncol, 26, 4473-4479.

Ross, D., Jones, M., Komanduri, K. \& Levy, R.B. (2013) Antigen and lymphopenia-driven donor $\mathrm{T}$ cells are differentially diminished by post-transplantation administration of cyclophosphamide after hematopoietic cell transplantation. Biol Blood Marrow Transplant, 19, 1430-1438. 
Sakaguchi, S., Yamaguchi, T., Nomura, T. \& Ono, M. (2008) Regulatory T cells and immune tolerance. Cell, 133, 775-787.

Sala, E., Crocchiolo, R., Gandolfi, S., Bruno-Ventre, M., Bramanti, S., Peccatori, J., Sarina, B., Corti, C., Ciceri, F., Santoro, A., Marktel, S. \& Castagna, L. (2014) Bendamustine combined with donor lymphocytes infusion in Hodgkin's lymphoma relapsing after allogeneic hematopoietic stem cell transplantation. Biol Blood Marrow Transplant, 20, 1444-1447.

Sampath, S., Schultheiss, T.E. \& Wong, J. (2005) Dose response and factors related to interstitial pneumonitis after bone marrow transplant. Int J Radiat Oncol Biol Phys, 63, 876-884.

Schultz, K.R., Paquet, J., Bader, S. \& HayGlass, K.T. (1995) Requirement for B cells in T cell priming to minor histocompatibility antigens and development of graft-versus-host disease. Bone Marrow Transplant, 16, 289-295.

Shi-Xia, X., Xian-Hua, T., Hai-Qin, X., Bo, F. \& Xiang-Feng, T. (2010) Total body irradiation plus cyclophosphamide versus busulphan with cyclophosphamide as conditioning regimen for patients with leukemia undergoing allogeneic stem cell transplantation: a metaanalysis. Leuk Lymphoma, 51, 50-60.

Solomon, S.R., Sizemore, C.A., Sanacore, M., Zhang, X., Brown, S., Holland, H.K., Morris, L.E. \& Bashey, A. (2015) Total Body Irradiation-Based Myeloablative Haploidentical Stem Cell Transplantation Is a Safe and Effective Alternative to Unrelated Donor Transplantation in Patients Without Matched Sibling Donors. Biol Blood Marrow Transplant, 21, 1299-1307.

Srinivasan, M., Flynn, R., Price, A., Ranger, A., Browning, J.L., Taylor, P.A., Ritz, J., Antin, J.H., Murphy, W.J., Luznik, L., Shlomchik, M.J., Panoskaltsis-Mortari, A. \& Blazar, B.R. (2012) Donor B-cell alloantibody deposition and germinal center formation are required for the development of murine chronic GVHD and bronchiolitis obliterans. Blood, 119, 15701580.

Switzer, G.E., Bruce, J.G., Myaskovsky, L., DiMartini, A., Shellmer, D., Confer, D.L., Abress, L.K., King, R.J., Harnaha, A.G., Ohngemach, S. \& Dew, M.A. (2013) Race and ethnicity in decisions about unrelated hematopoietic stem cell donation. Blood, 121, 1469-1476.

Sykes, M. (1990) Unusual T cell populations in adult murine bone marrow. Prevalence of CD3+CD4-CD8- and alpha beta TCR+NK1.1+ cells. J Immunol, 145, 3209-3215.

Tageja, N. \& Nagi, J. (2010) Bendamustine: something old, something new. Cancer Chemother Pharmacol, 66, 413-423.

Taylor, P.A., Panoskaltsis-Mortari, A., Swedin, J.M., Lucas, P.J., Gress, R.E., Levine, B.L., June, C.H., Serody, J.S. \& Blazar, B.R. (2004) L-Selectin(hi) but not the L-selectin(lo) CD4+25+ T-regulatory cells are potent inhibitors of GVHD and BM graft rejection. Blood, 104, 3804-3812.

von Vietinghoff, S. \& Ley, K. (2008) Homeostatic regulation of blood neutrophil counts. J Immunol, 181, 5183-5188.

Young, J.S., Wu, T., Chen, Y., Zhao, D., Liu, H., Yi, T., Johnston, H., Racine, J., Li, X., Wang, A., Todorov, I. \& Zeng, D. (2012) Donor B cells in transplants augment clonal expansion and survival of pathogenic CD4+ T cells that mediate autoimmune-like chronic graftversus-host disease. J Immunol, 189, 222-233.

Zeiser, R., Leveson-Gower, D.B., Zambricki, E.A., Kambham, N., Beilhack, A., Loh, J., Hou, J.Z. \& Negrin, R.S. (2008) Differential impact of mammalian target of rapamycin inhibition on CD4+CD25+Foxp3+ regulatory T cells compared with conventional CD4+ T cells. Blood, 111, 453-462.

Zeiser, R., Nguyen, V.H., Beilhack, A., Buess, M., Schulz, S., Baker, J., Contag, C.H. \& Negrin, R.S. (2006) Inhibition of CD4+CD25+ regulatory T-cell function by calcineurin-dependent interleukin-2 production. Blood, 108, 390-399. 
Zeng, Y., Stokes, J., Hahn, S., Hoffman, E. \& Katsanis, E. (2014) Activated MHC-mismatched T helper-1 lymphocyte infusion enhances GvL with limited GvHD. Bone Marrow Transplant, 49, 1076-1083.

Zuluaga, A.F., Salazar, B.E., Rodriguez, C.A., Zapata, A.X., Agudelo, M. \& Vesga, O. (2006) Neutropenia induced in outbred mice by a simplified low-dose cyclophosphamide regimen: characterization and applicability to diverse experimental models of infectious diseases. BMC Infect Dis, 6, 55. 


\section{Figure Legends}

Figure 1: Survival from GvHD following MAC and RIC haploidentical BMT (h-BMT) increases with PT-CY. CAF1/J mice $\left(\mathrm{H}-2^{\mathrm{d} / \mathrm{a}}\right)$ received MAC $1000 \mathrm{cGy}$ or RIC $600 \mathrm{cGy}$ TBI on day -1 and $h-B M\left(10^{7}\right)$ with or without $h-S C\left(3 \times 10^{7}\right)$ from CB6F1 mice $\left(\mathrm{H}-2^{d / b}\right)$ on day 0 . PT-CY $75 \mathrm{mg} / \mathrm{kg}$ was given i.p. on days +3 and +4 . Pooled data from 4 experiments (MAC; $\mathrm{n}=16$ ) and 6 experiments (RIC; $n=24)$. Kaplan-Meier survival curves were generated and analyzed using the log-rank test. MAC: $h-B M T / S C+P T-C Y$ vs $h-B M T / S C$ and $h-B M T P<.0001$. RIC: $h$ $B M T / S C+P T-C Y$ vs $h-B M T / S C P<.0001$ and vs $h-B M T P<.035$.

Figure 2: PT-BEN preserves engraftment following MAC and RIC $h-B M T$. CAF1/J mice $(H-$ $2^{\text {d/a }}$ ) received MAC or RIC TBI, $(A) h-B M T$ from CB6F1 mice $\left(H-2^{d / b}\right)$, (B) h-BMT/SC, (C) h$\mathrm{BMT} / \mathrm{SC}$ and PT-BEN (30 mg/kg day +3 or $15 \mathrm{mg} / \mathrm{kg}$ days +3 and +4 i.v.). Percentage donor chimerism determined by flow cytometry is shown. Peripheral blood cells were gated on live cells from $\mathrm{FSC} / \mathrm{SSC}$ and then gated on $\mathrm{H} 2 \mathrm{k}^{\mathrm{b+}}$ cells. MAC $\mathrm{n}=16$ mice (pooled data from 4 experiments), RIC n=16 (PT-BEN) or 32 (h-BMT and h-BMT/SC) micelgroup (pooled data from at least 4 experiments).

Figure 3: PT-BEN is as efficient as PT-CY at mitigating GvHD in $\mathrm{h}-\mathrm{BMT}$. CAF1/J mice received MAC or RIC TBI on day -1 and $h-B M\left(10^{7}\right)$ with $\mathrm{h}-\mathrm{SC}\left(3 \times 10^{7}\right)$ from CB6F1 mice on day 0 . PT-BEN $30 \mathrm{mg} / \mathrm{kg}$ was given on day +3 and PT-CY $75 \mathrm{mg} / \mathrm{kg}$ was given on days +3 and +4 . Kaplan-Meier survival curves were generated and analyzed using the log-rank test. (A) Overall survival is shown. $\mathrm{n}=12-16$ mice/group, pooled data from at least 3 experiments. MAC: $h$ $B M T / S C$ vs $h-B M T / S C+P T-B E N$ and vs $h-B M T / S C+P T-C Y P<.0001, h-B M T / S C+P T-B E N$ vs $h-$ $B M T / S C+P T-C Y P=n s$. RIC: $h-B M T / S C$ vs $h-B M T / S C+P T-B E N P<.004$ and vs $h-B M T / S C+P T-$ $C Y P=.017$. $h-B M T / S C+P T-B E N$ vs $h-B M T / S C+P T-C Y P=n s$. (B) Mean percent weight change with SEM based on pre-transplant weight. (C) Mean clinical GVHD scores (based on weight, skin integrity, fur, activity and posture) with SEM. Shown are representative data from 4 experiments. $n=4$ (RIC) or 8 (MAC) mice/group.

Figure 4: PT-BEN and PT-CY show comparable levels of colonic and hepatic GvHD. CAF1/J mice received RIC TBI on day -1 and h-BM $\left(10^{7}\right)$ with $\mathrm{h}-\mathrm{SC}\left(3 \times 10^{7}\right)$ from CB6F1 mice on day 0 . PT-BEN $30 \mathrm{mg} / \mathrm{kg}$ and PT-CY $75 \mathrm{mg} / \mathrm{kg}$ were given on days +3 and +4 . (A) Proximal and distal colons were collected and blindly scored for abnormalities. $n=4$ mice/group. Total colon scores (sum of proximal and distal scores) from days $+21,+35$ and +49 are shown. (B) Representative images of hematoxylin and eosin staining of distal colons collected on day +21 are shown at 50X magnification. (C) Representative images of hematoxylin and eosin staining of livers collected on day +21 are shown at 50X magnification.

Figure 5: PT-BEN is protective against GvHD even in the absence of donor CD25+ Tcells. Recipient CAF1/J mice received RIC and T-cell depleted h-BM $\left(10^{7}\right)$ with $6 \times 10^{6}$ total Tcells or $6 \times 10^{6}$ CD25-depleted T-cells from CB6F1 mice on day 0. PT-BEN $30 \mathrm{mg} / \mathrm{kg}$ was given on day +3 . Shown are survival data and mean clinical GvHD scores with SEM. Representivative data from 2 experiments, $n=6$ mice/group. Kaplan-Meier survival curves were generated and 
analyzed using the log-rank test. $C D 25^{-} T$ vs $C D 25^{-} T+P T-B E N P<.002$, total $T$ vs $C D 25^{-} T+P T$ $B E N P=n s$, total $T$ vs CD25 $T P<.03$.

Figure 6: PT-BEN is less myelosuppressive than PT-CY following MAC and RIC h-BMT. CAF1/J mice received MAC or RIC TBI on day -1 and $h-B M T / S C$ from CB6F1 mice on day 0. PT-BEN $30 \mathrm{mg} / \mathrm{kg}$ was given on day +3 and PT-CY $75 \mathrm{mg} / \mathrm{kg}$ was given on days +3 and +4 . Peripheral blood was collected on the indicated days by tail tipping. (A) Day +7 white blood cell (WBC) counts broken down into myeloid/lymphoid differentials are shown with SEM. Blood was analyzed using a HemaVet blood counter and broken down into neutrophils, monocytes, eosinophils, basophils (myeloid) and lymphocytes (lymphoid). MAC n=8 mice/group, RIC n=14 mice/group (pooled data from 2-3 experiments). (B) Absolute numbers of donor $\mathrm{CD}^{+} \mathrm{FoxP}^{+}$ Treg are shown. $n=4-8$ (pooled data from 2-3 experiments). (C, D) Absolute numbers of donor CD4, CD8 and B-cells in peripheral blood are shown. Cells were stained with anti-H2 ${ }^{b}, C D 4$, CD8 and B220 and analyzed by flow cytometry. Cells were gated on live cells from FSC/SSC, $\mathrm{H} 2 \mathrm{k}^{\mathrm{b}+}$ cells and then on $\mathrm{CD}^{+}, \mathrm{CD}^{+}$or $\mathrm{B}^{2} 2 \mathrm{O}^{+}$and absolute cell number was calculated based on total WBC count. (E) Absolute number of donor CD11 b+ Gr-1 hi cells is shown. Day +7 and +14 blood was stained with anti-H2 $\mathrm{k}^{\mathrm{b}}, \mathrm{Gr}-1$ and $\mathrm{CD} 11 \mathrm{~b}$ and analyzed by flow cytometry. Cells were gated on live cells from FSC/SSC, $\mathrm{H}_{2} \mathrm{k}^{\mathrm{b}+}$ cells and then on CD11 $\mathrm{b}^{+} \mathrm{Gr}-1^{\mathrm{hi}}$. Gating strategy and representative flow from RIC day +14 are shown. Absolute cell number was calculated using the WBC count and difference were analyzed using Mann-Whitney test. ${ }^{*}=P<.05$, ${ }^{* *}=P<.01,{ }^{* * *}=P<.001,{ }^{* * * *}=P<.0001$.

Figure 7: BEN treatment in vitro enhances MDSC function and decreases the proliferation of CD4+ and CD8+ T-cells and B-cells. (A) MDSCs were generated using BM cells from naïve CB6F1 mice. BM cells were cultured for 3 days with $10 \mathrm{ng} / \mathrm{mL}$ murine IL-6, murine GM-CSF and human G-CSF and various concentrations of BEN (0-100 $\mu \mathrm{M})$. MDSCs were then co-cultured for 3 days with CellTrace Violet stained, stimulated total T-cells from naïve CB6F1 spleens at a ratio of 1 MDSC to 2 T-cells. Average \% T-cell proliferation (with SEM) after 3 days of co-culture is shown. Pooled data from 5 experiments and representative ModFit analysis with proliferation index are shown. This includes T-cells without MDSCs as a negative control for suppression. Significance is shown as compared to $0 \mu \mathrm{M}$ BEN, using Mann-Whitney tests. (B) T-cells isolated from the spleens of naïve CB6F1 mice were CellTrace stained, stimulated with CD3/CD28 beads and cultured for 3 days in the presence of various concentrations of BEN. On day 3 , viability was determined and T-cells were stained with anti-CD4 and CD8 for proliferation analysis by flow cytometry. Cells were gated on live cells, $\mathrm{CD}^{+}$or $\mathrm{CD}^{+}$and then CellTrace fluorescence was analyzed. Shown are pooled data from 4 experiments. (C) B-cells isolated from the spleens of naïve CB6F1 mice were CellTrace stained, stimulated with $10 \mu \mathrm{g} / \mathrm{mL}$ LPS and cultured for 5 days in the presence of various concentrations of BEN. Shown are pooled data from 4 experiments. Viability and average percent proliferation as compared to the culture with $0 \mu \mathrm{M}$ BEN are shown, using Mann-Whitney tests. ${ }^{*}=P<.05, \quad{ }^{*}=P<.01, \quad * * *=P<.001$, $\star \star \star * *=P<.0001$.

Figure 8: BEN has minimal direct anti-tumor activity against $A 20$ leukemia and preserves GvL when given post-h-BMT. A20 leukemia-bearing (A) BALB/C and (B) NOD-scid IL2Ry null were treated with BEN $30 \mathrm{mg} / \mathrm{kg}$ or $\mathrm{CY} 75 \mathrm{mg} / \mathrm{kg} 5$ and 6 days post injection of $10^{6} \mathrm{~A} 20$ cells. $C Y$ vs BEN $P<.002$ in BALB/C and $P<.006$ in NOD-scid IL2Ry ${ }^{\text {null }}, \mathrm{n}=4$ (BALB/C) or 8 (NOD-scid) mice/group. (C) CAF1/J mice received $10^{6}$ A20 tumor cells i.v. on day $-4, \mathrm{RIC}$ TBI on day -1 and h-BM $\left(10^{7}\right)$ or h-BMT with h-SC $\left(3 \times 10^{7}\right)$ from CB6F1 mice on day 0. PT-BEN $30 \mathrm{mg} / \mathrm{kg}$ as a 
single dose or divided over 2 days was given starting on day +3 . Pooled data from 5 experiments, $n=20-34$ mice/group. Kaplan-Meier survival curves were generated and analyzed using the log-rank test. $h-B M T$ vs $h-B M T / S C+P T-B E N \quad P<.002$. (D) CAF1/J mice received RIC TBI on day -1 and $\mathrm{h}-\mathrm{BMT}$ or $\mathrm{h}-\mathrm{BMT} / \mathrm{SC}$ from CB6F1 mice on day 0 . PT-BEN $(33 \mathrm{mg} / \mathrm{kg})$ or $\mathrm{CY}$ $\left(150 \mathrm{mg} / \mathrm{kg}\right.$ ) was given on day +3 and $1 \times 10^{5} \mathrm{~A} 20$-Luc cells were injected i.v on day $+4 . h-$ $B M T / S C+P T-B E N$ vs $h-B M T P<.0004$ and vs $h-B M T / S C+P T-C Y P<.0005, h-B M T / S C+P T-C Y$ vs $h-B M T P=n s$. Pooled data from 2 experiments, $\mathrm{n}=8$ mice/group.

Figure 9: PT-BEN preserves GvL when given post-h-BMT. (A) CAF1/J recipient mice received RIC on day -1 and T-cell depleted h-BMT or h-BMT/SC from CB6F1 mice on day 0. PT-BEN or PT-CY was given day +3 and $0.5 \times 10^{6}$ A20-Luc cells on day +4 . Mice were injected with luciferin and imaged serially. At times, cages were imaged concurrently, so images are cropped to only show mice from the indicated group. (B) Quantification of $(A)$ is shown in $\ln$ (photons/second/mouse). Group average with SEM is shown (left) until any mouse from the group died and analyzed using Mann-Whitney tests. Individual mouse values are also shown (right). Images were analyzed using AmiView. $n=4-5$ mice/group. 
MAC

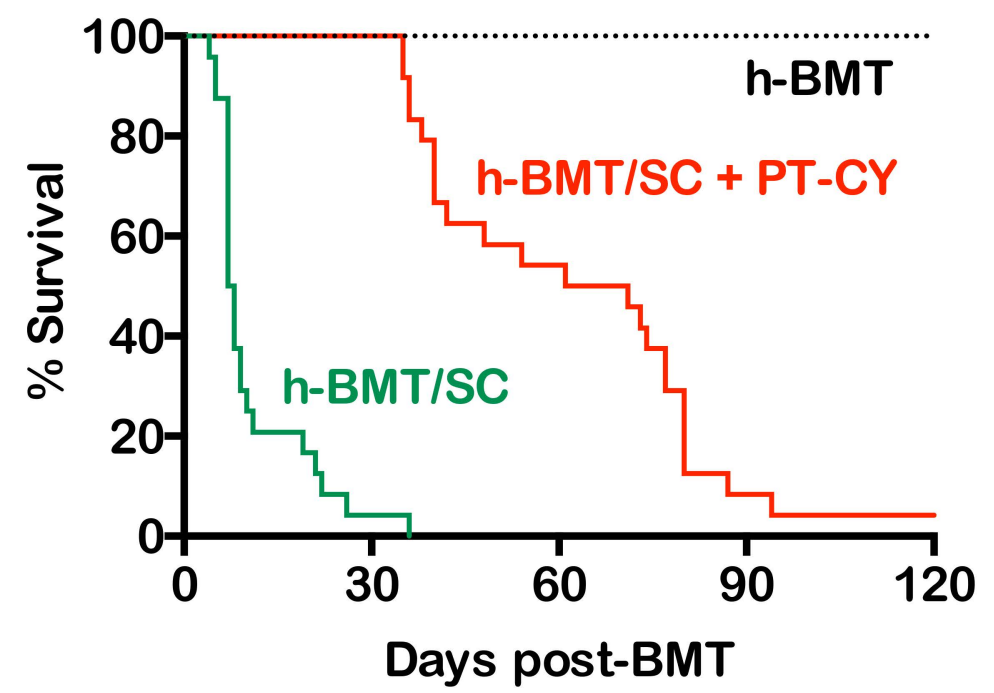

RIC

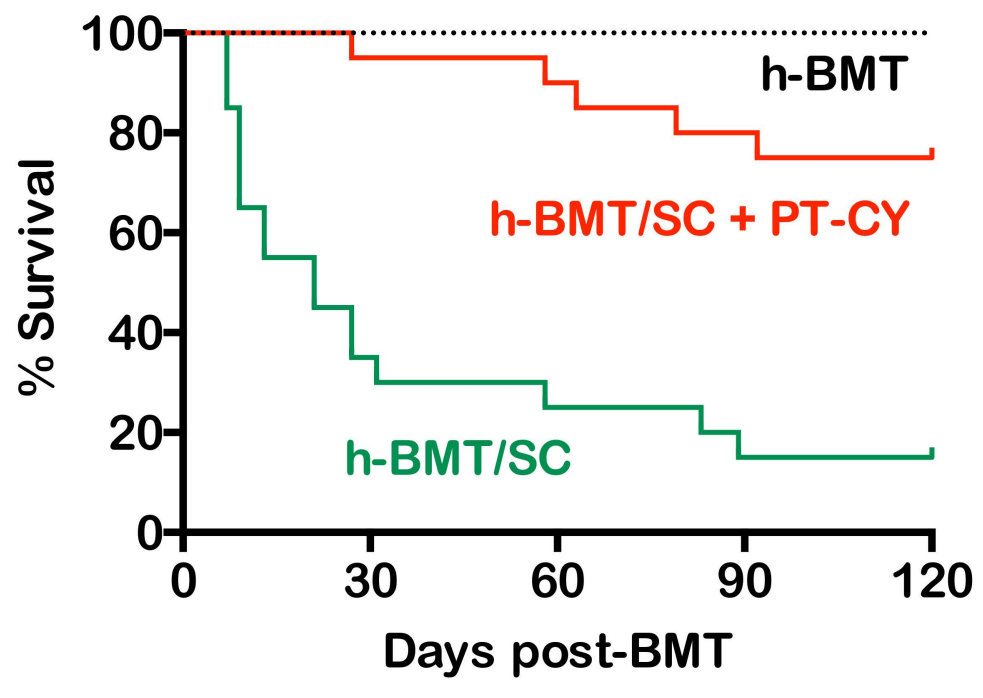


MAC

A h-BMт

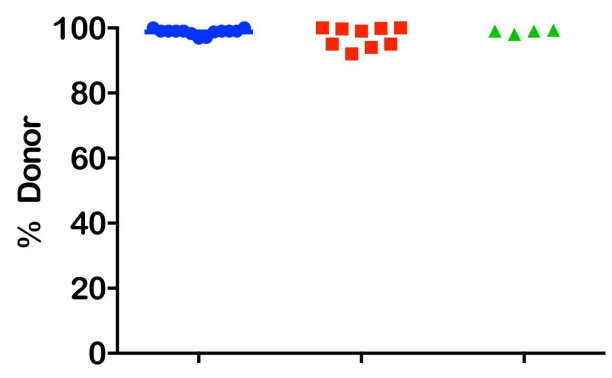

B h-BMT/SC

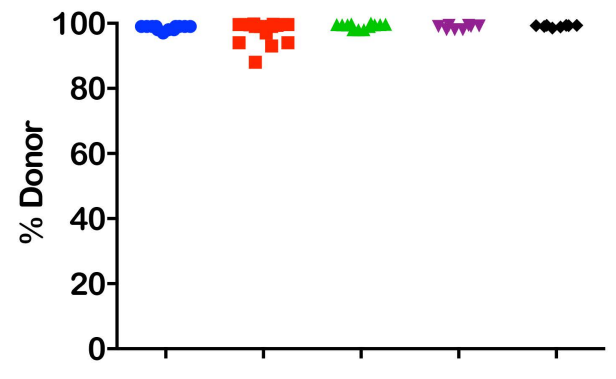

C h-BMT/SC

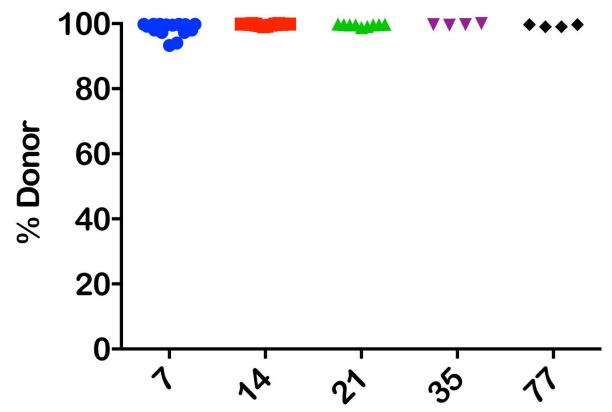

RIC
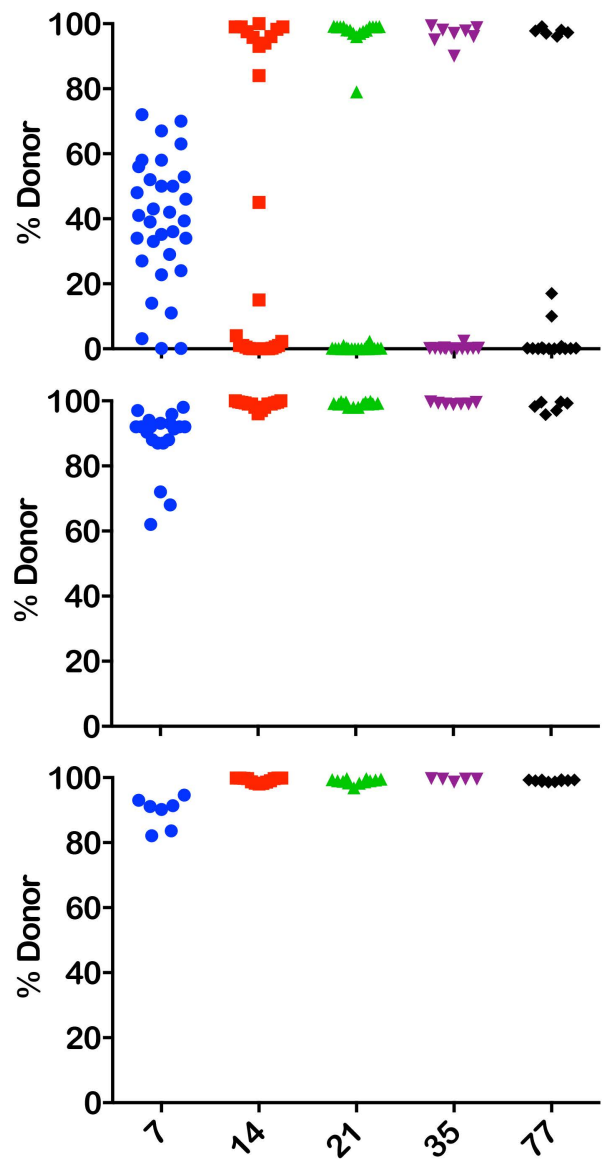

Days post-BMT 


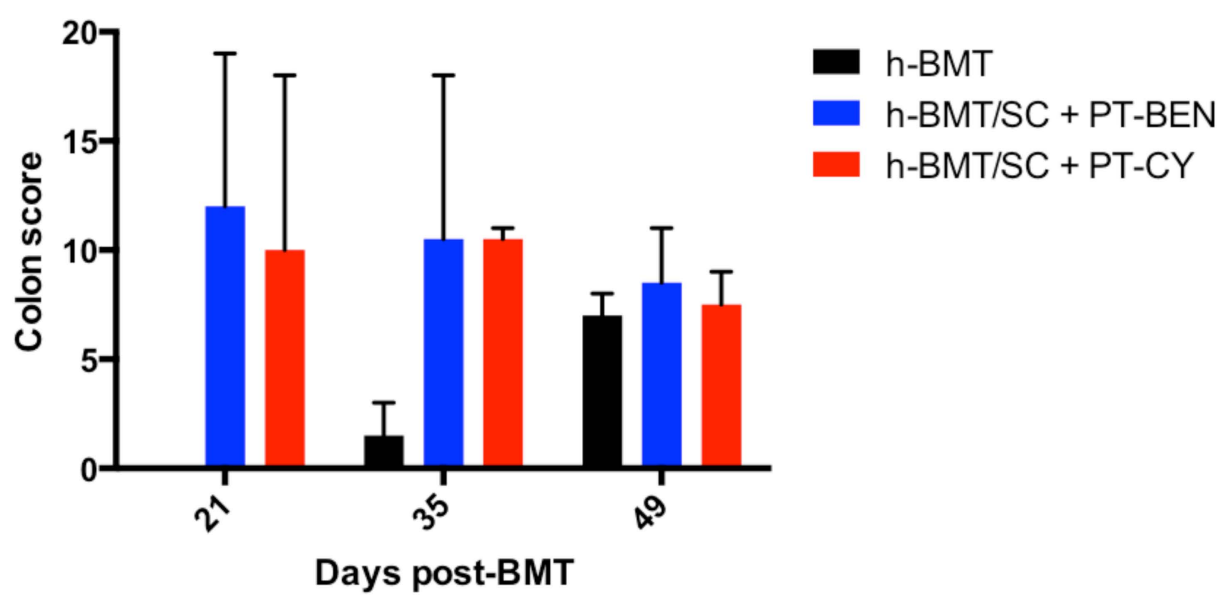

B

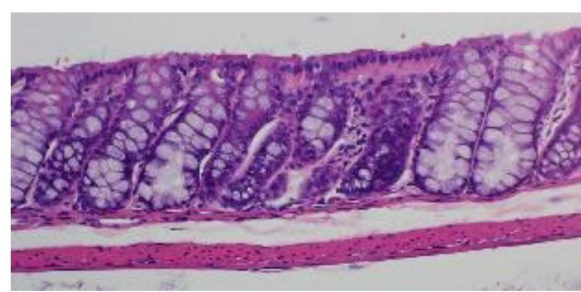

h-BMT

C

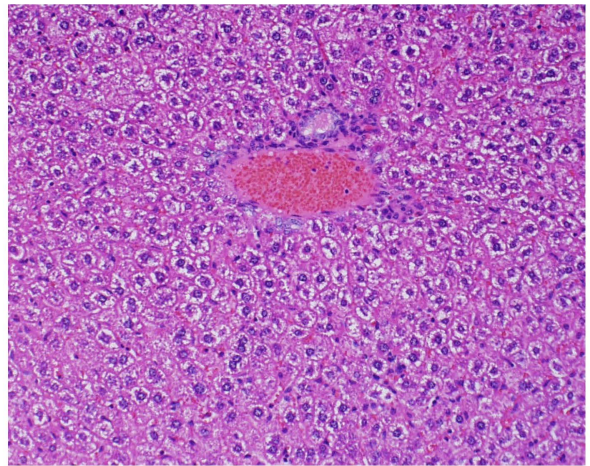

h-BMT

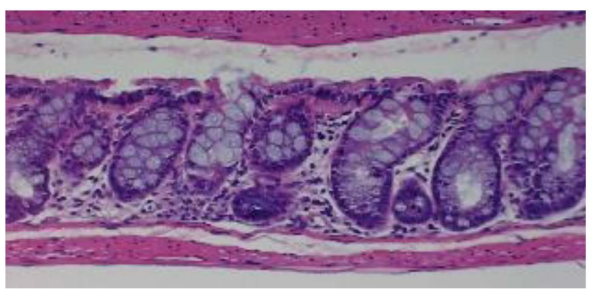

h-BMT/SC + PT-BEN

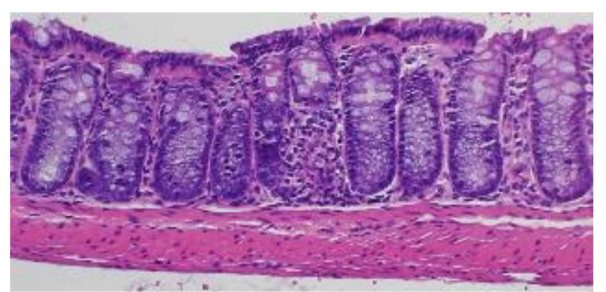

h-BMT/SC + PT-CY

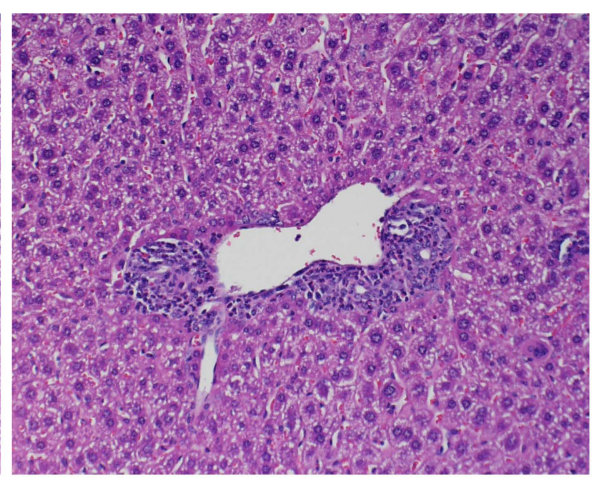

h-BMT/SC + PT-BEN

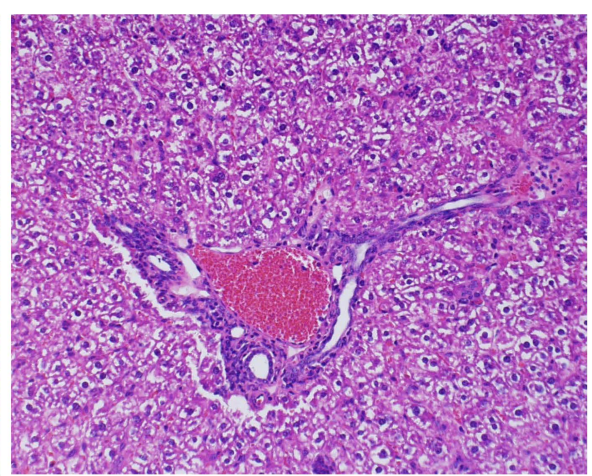

h-BMT/SC + PT-CY 

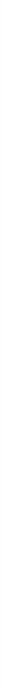


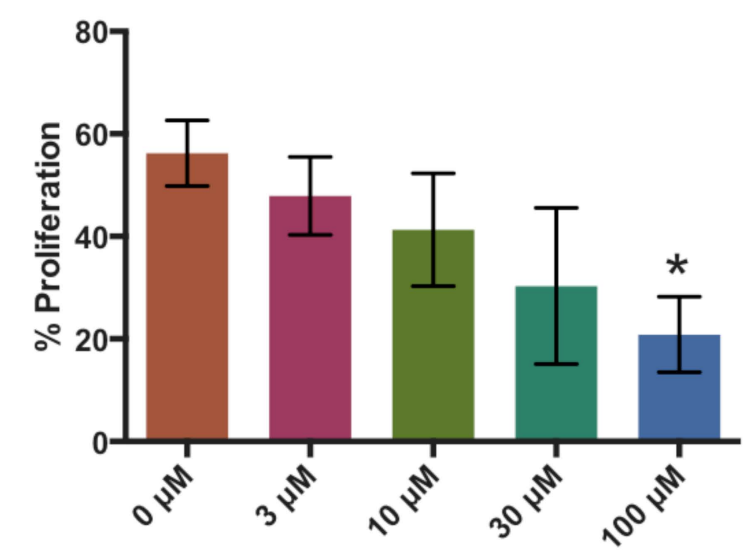

Stimulated T-cells

without MDSCs
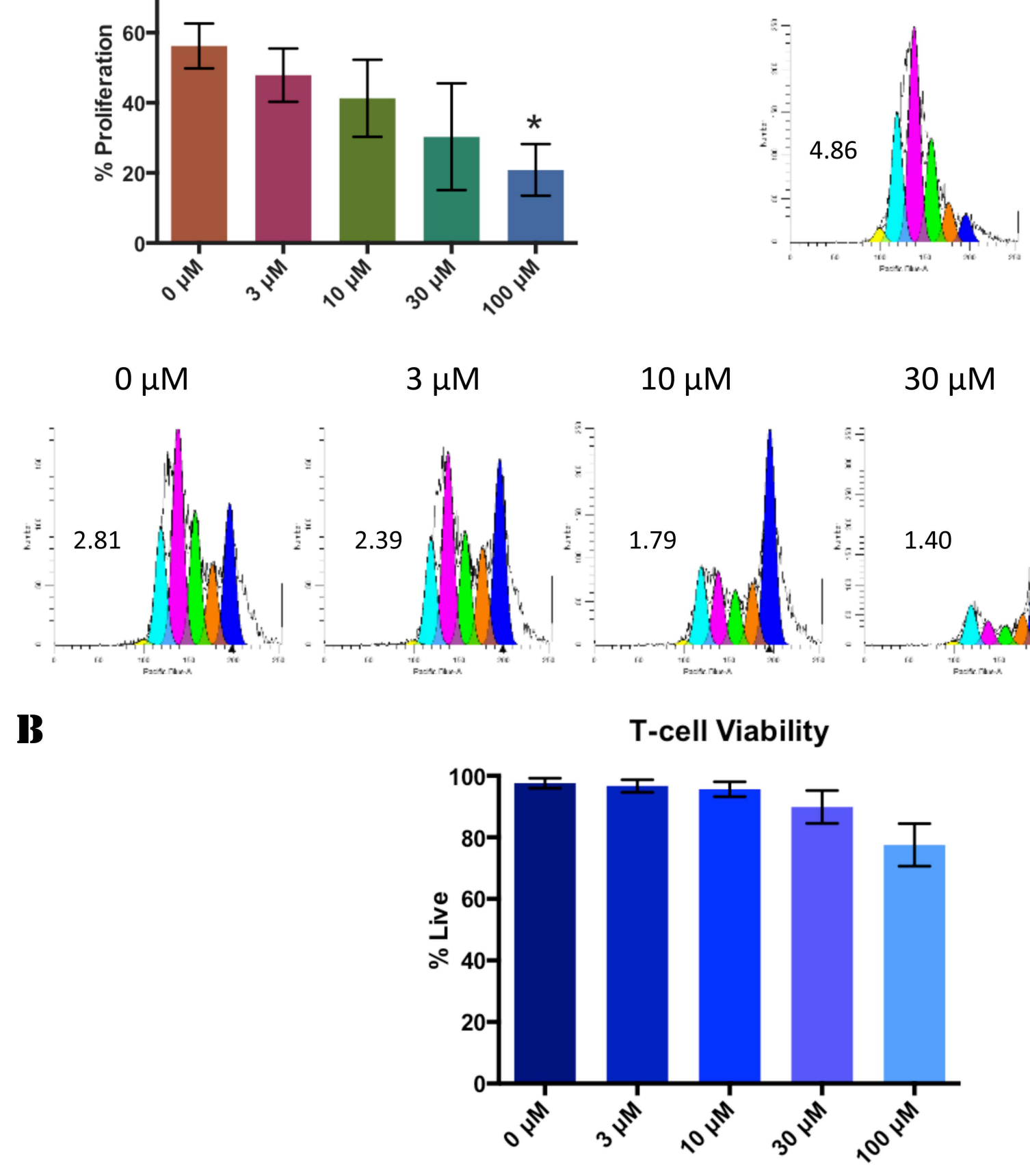

CD4

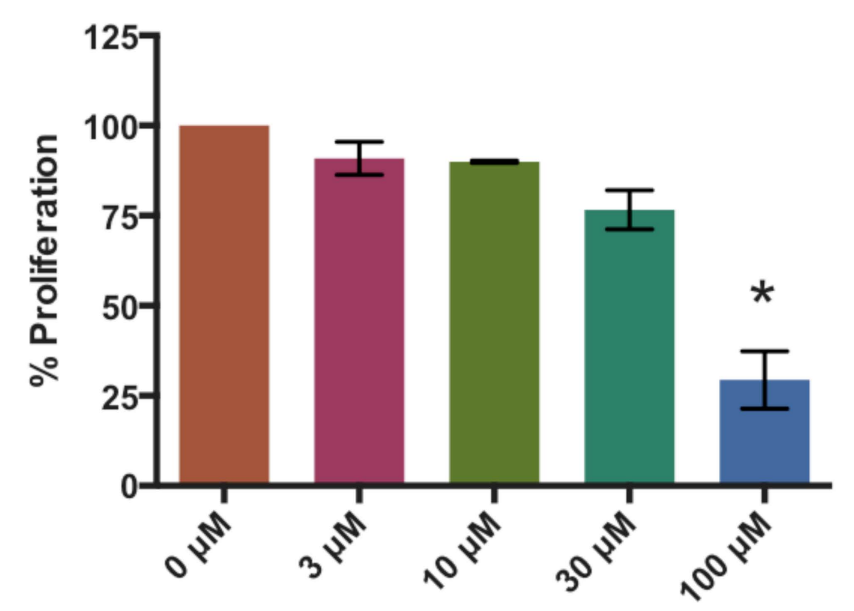

c

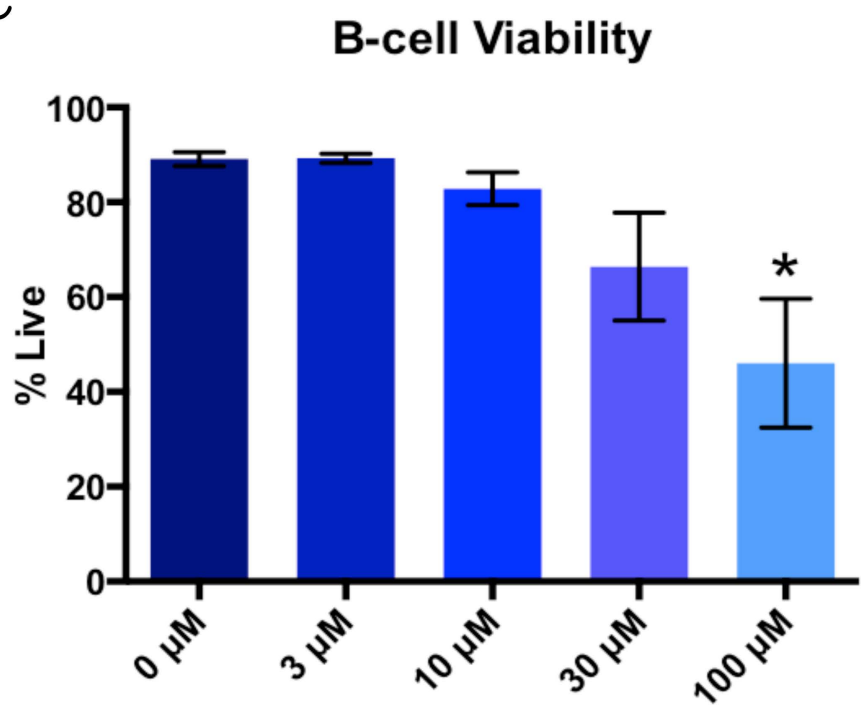

CD8

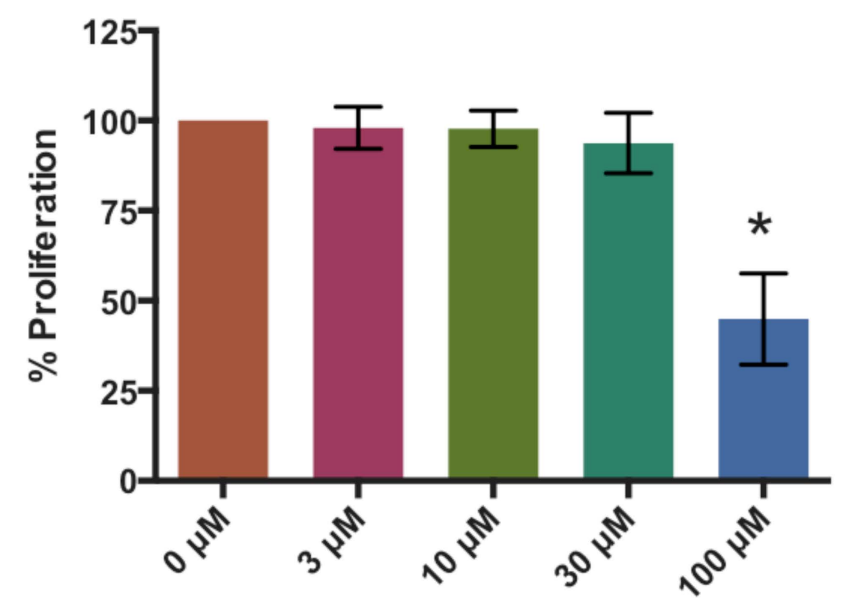

B-cells

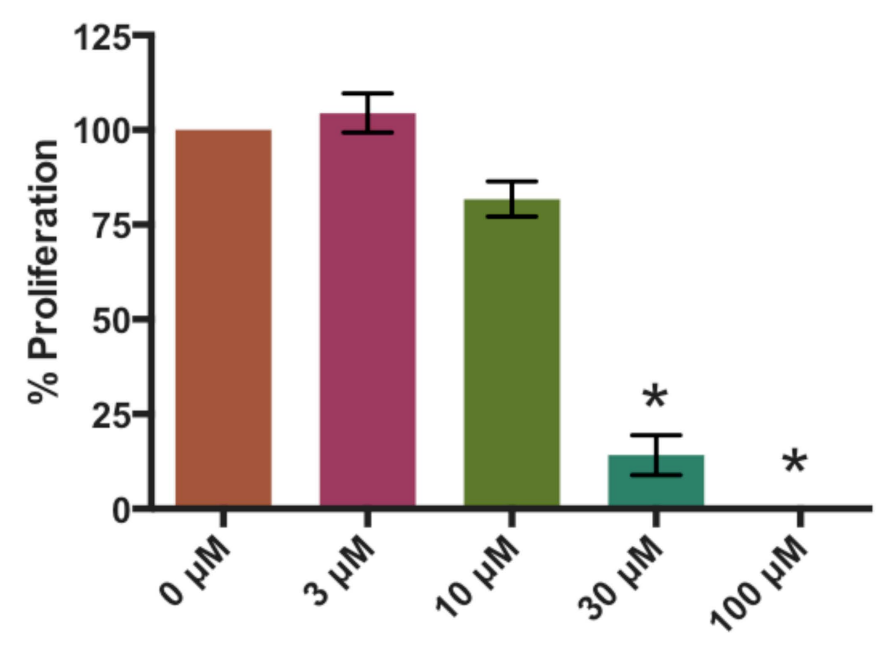



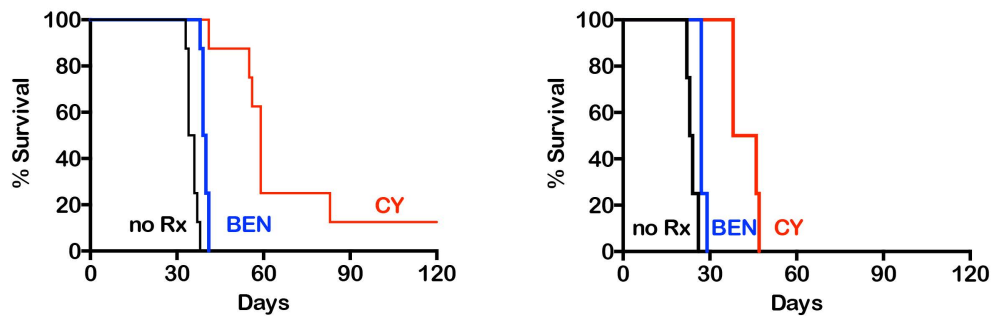

C

\section{Pre-BMT A20}

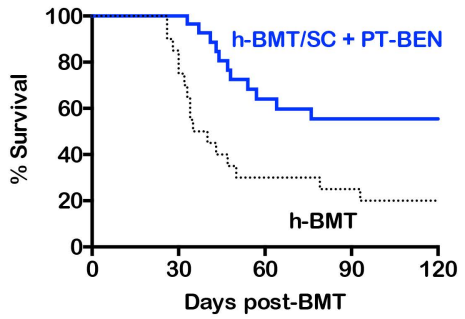

Post BMT-A20 luc

)

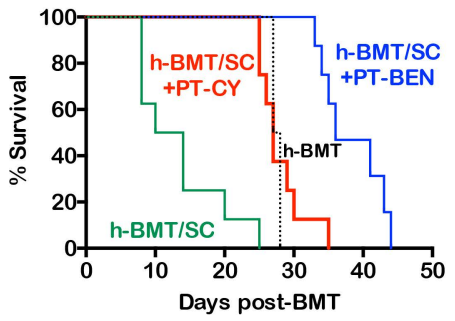


A Days
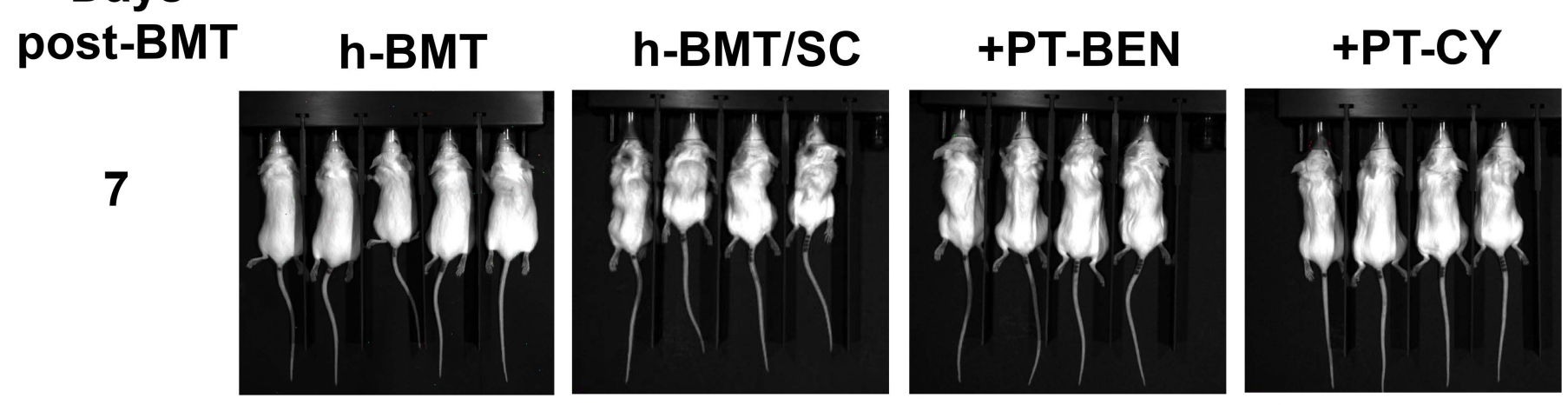

22
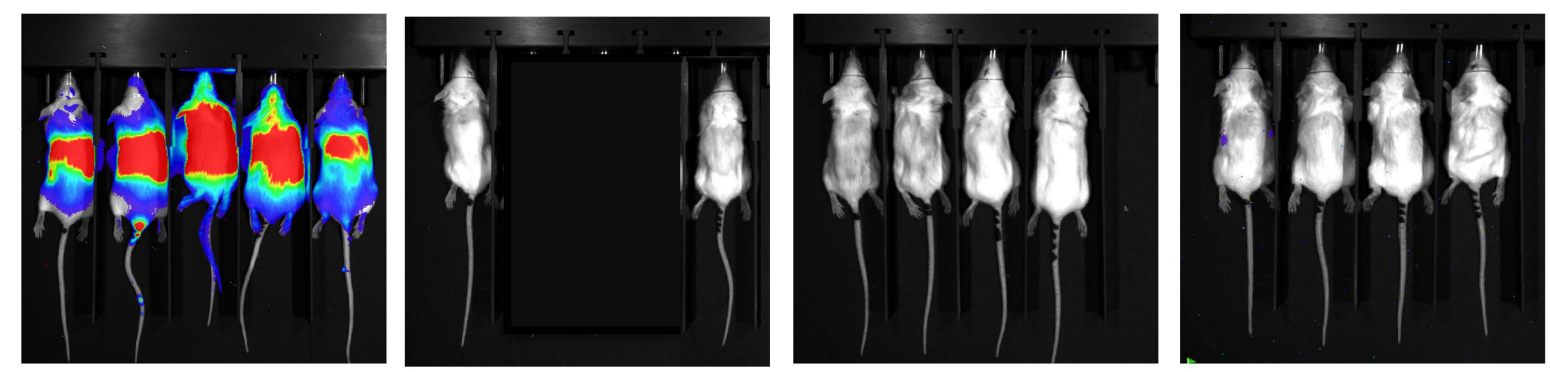

29
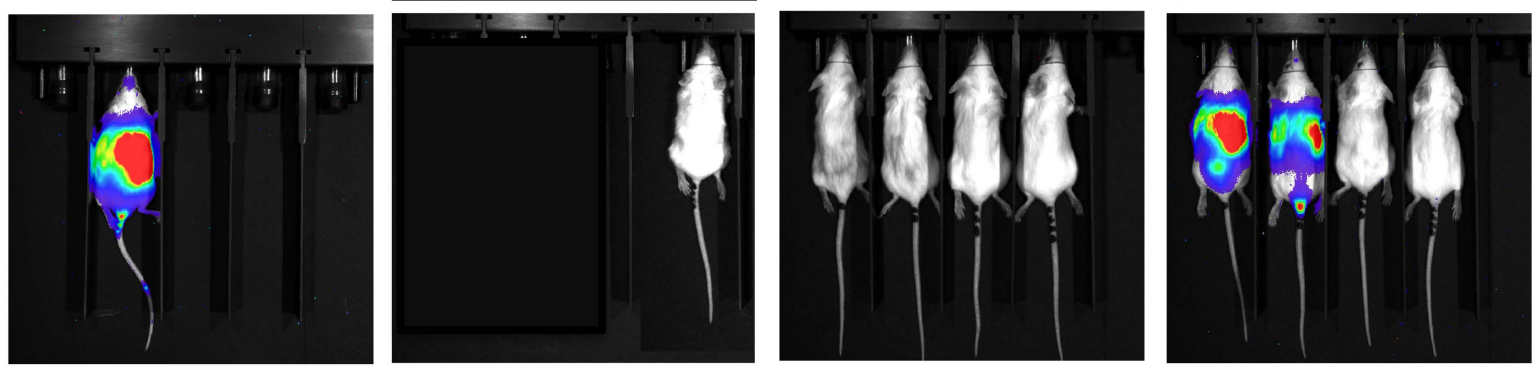

36
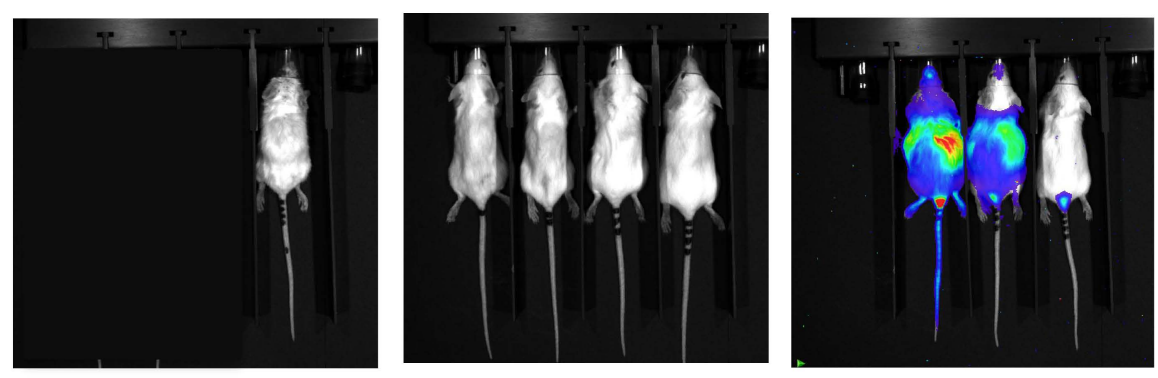

46
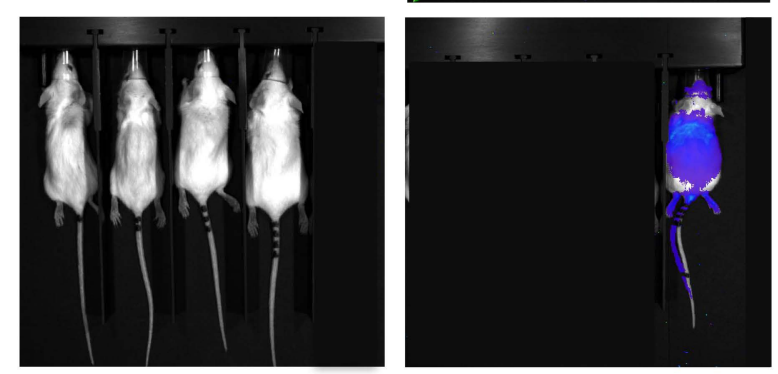

61

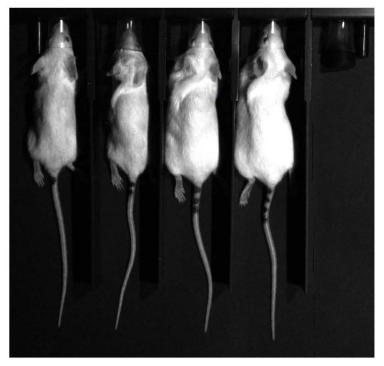

B
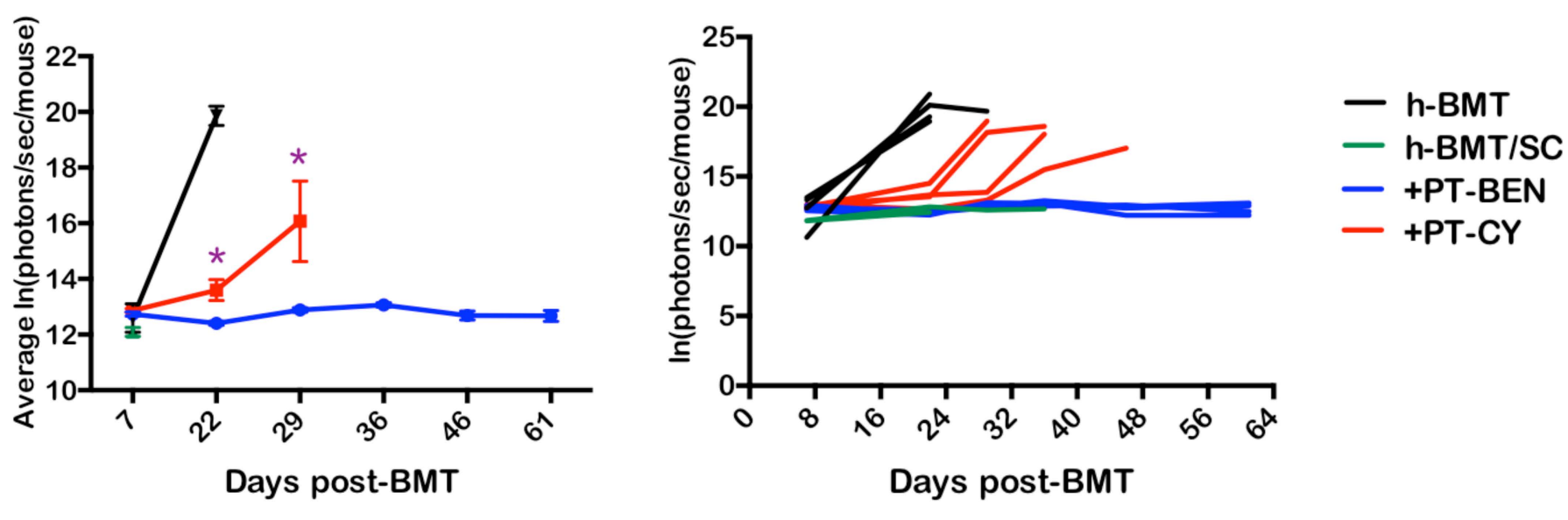
1 Supplemental Figure 1: Survival from GvHD in two different models is shown. For the 2 parent $\rightarrow F 1$ model $(\mathrm{P} \rightarrow \mathrm{F} 1)$, CB6F1 mice $\left(\mathrm{H}^{\mathrm{d} / \mathrm{b}}\right)$ received $\mathrm{RIC} 600 \mathrm{cGy}$ TBI on day -1 and $10^{7}$ 3 BM cells with $3 \times 10^{7} \mathrm{SC}$ on day 0 from C57BL/6 $\left(\mathrm{H} 2^{b}\right)$ donors. For the F1 $\rightarrow \mathrm{F} 1$ model, CAF1/J 4 mice $\left(\mathrm{H}-2^{\mathrm{d} / \mathrm{a}}\right)$ received $\mathrm{RIC} 600 \mathrm{cGy}$ TBI on day -1 and $10^{7} \mathrm{BM}$ cells and $3 \times 10^{7} \mathrm{SC}$ on day 0 from 5 CB6F1 $\left(\mathrm{H}-2^{d / b}\right)$ donors. $n=10-12$ mice/group. Kaplan-Meier survival curves were generated and 6 analyzed using the log-rank test. $P<.0001$.

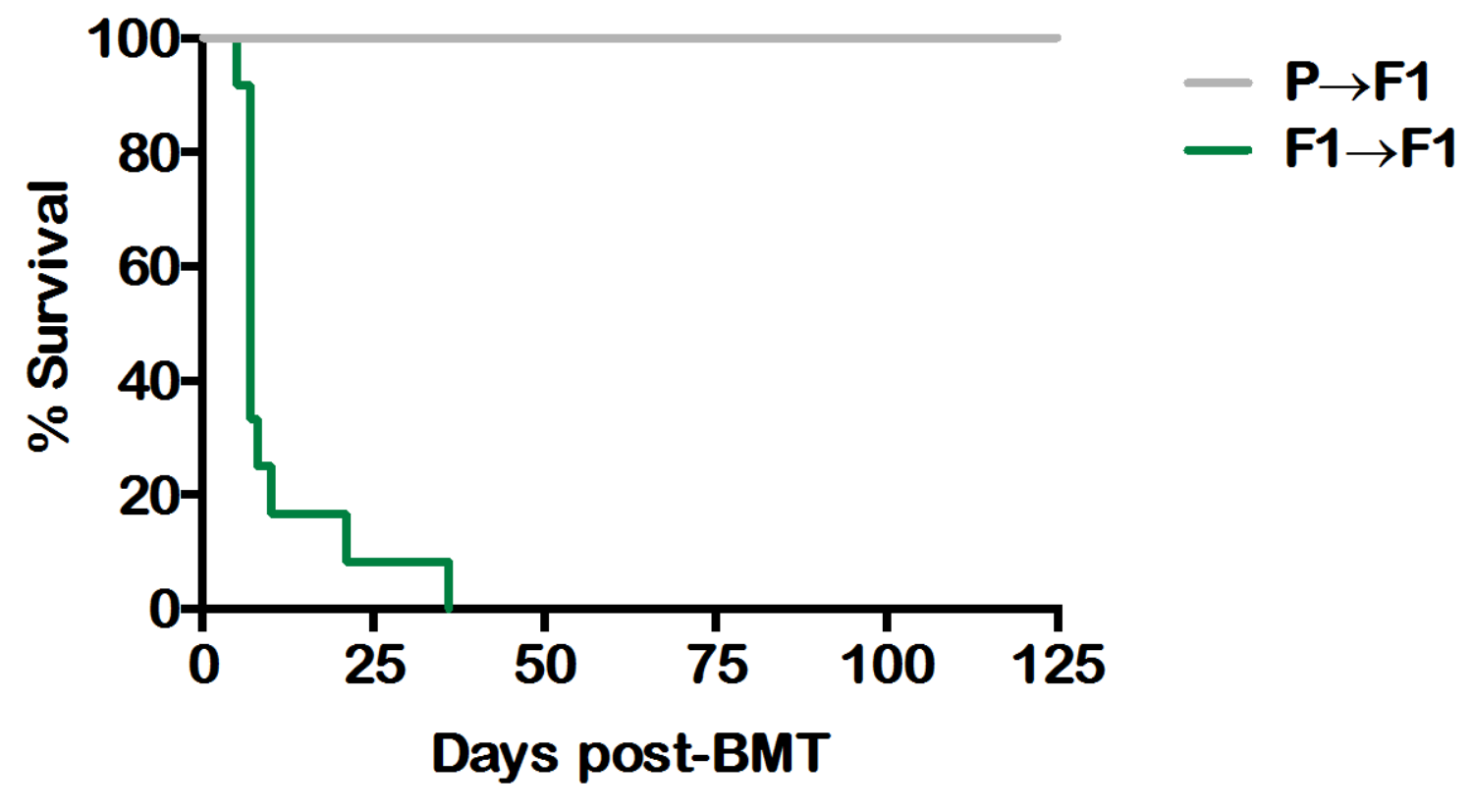


1 Supplemental Figure 2: CAF1/J mice received RIC and h-BMT/SC. Mice were given PT-BEN

2 i.v. at various doses on various days. Overall survival is shown. Data pooled from 2-5 3 independent experiments. $n=8-25$ mice.

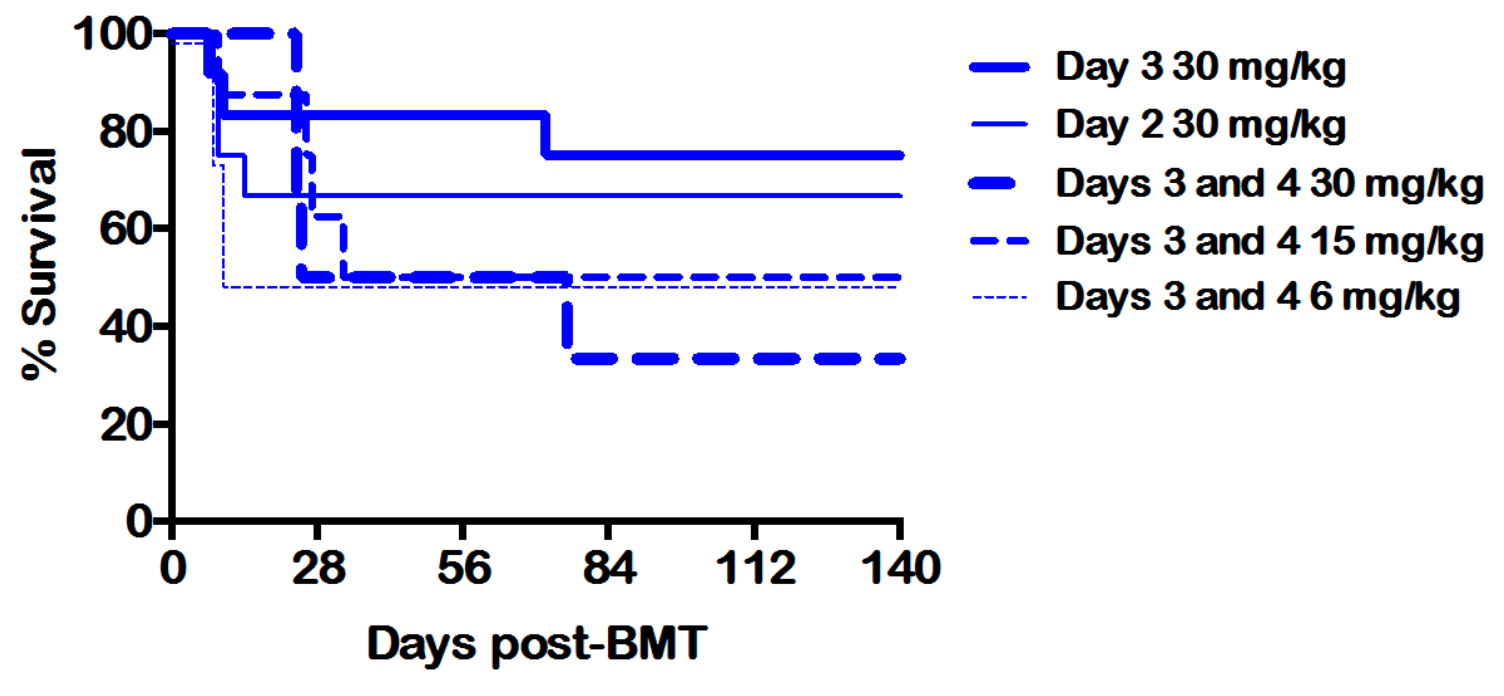


1 Supplemental Figure 3: CAF1/J mice received BEN i.v. or CY i.p. on day 0. Survival through 2 day +14 is shown. $\mathrm{n}=4-8$ mice/group.

\section{BEN}

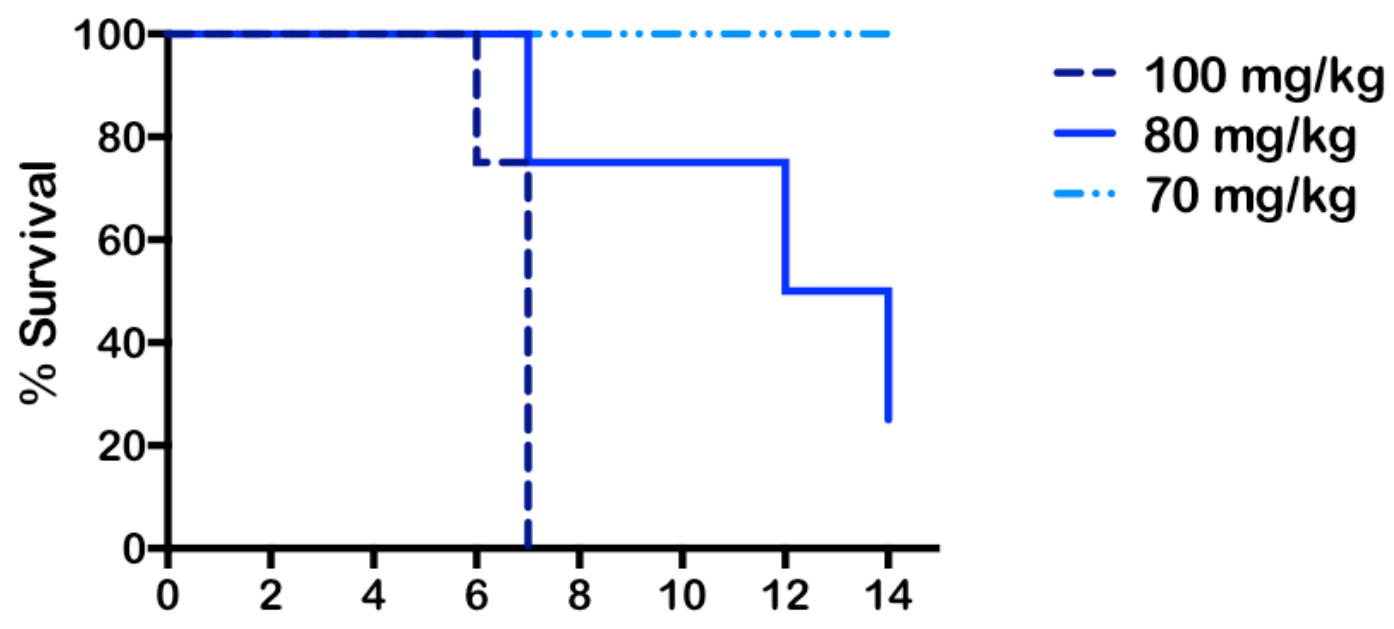

3
4

Days post-injection

\section{CY}

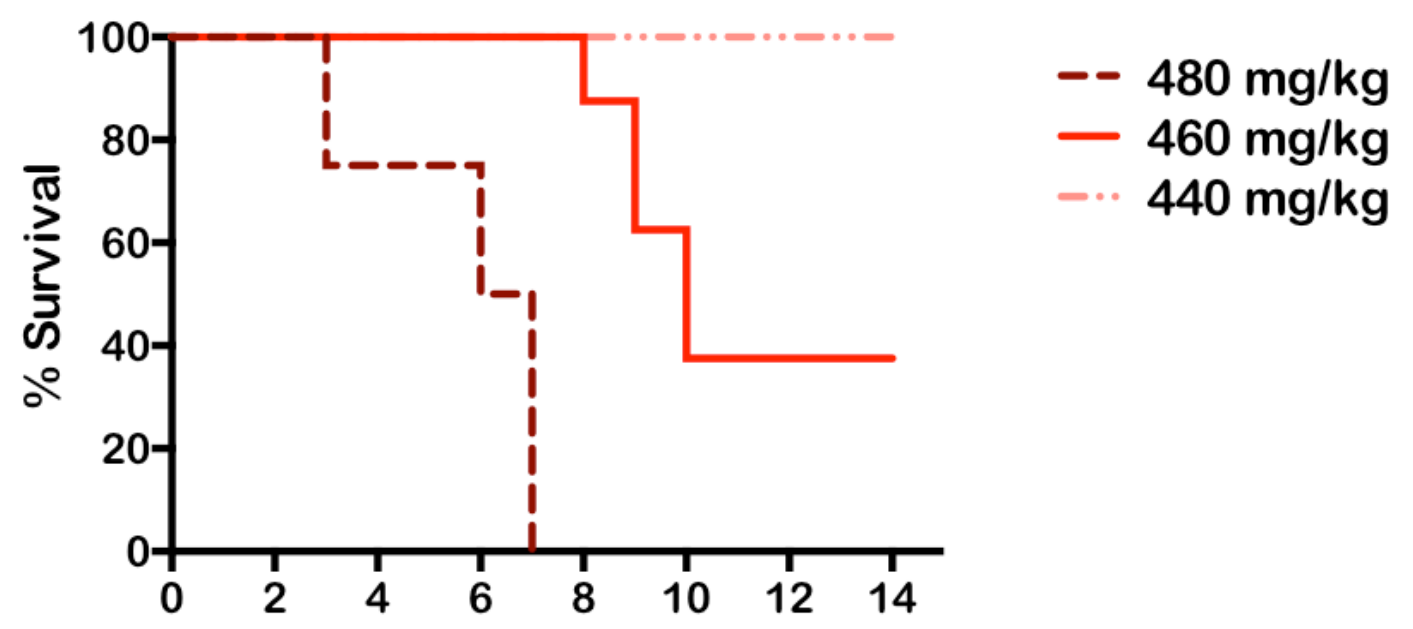


1 Supplemental Figure 4: CAF1/J mice received RIC TBI on day -1 and h-BMT/SC from CB6F1 2 mice on day 0. PT-BEN $30 \mathrm{mg} / \mathrm{kg}$ and PT-CY $150 \mathrm{mg} / \mathrm{kg}$ were given on day +3 . Peripheral 3 blood was collected on the indicated days by tail tipping. (A) Day +4 through +14 white blood 4 cell (WBC) counts are shown with SEM. (B) The ratio of myeloid cells to lymphoid cells with 5 SEM is shown on days +4-14. (C) The number of neutrophils with SEM is shown on days +4-14. 6 Blood was analyzed using a HemaVet blood counter. $n=5$ mice/group. Significance was 7 determined by Mann-Whitney tests. ${ }^{*}=P<.05,{ }^{* *}=P<.01,{ }^{* * *}=P<.001,{ }^{* * *}=P<.0001$.

A

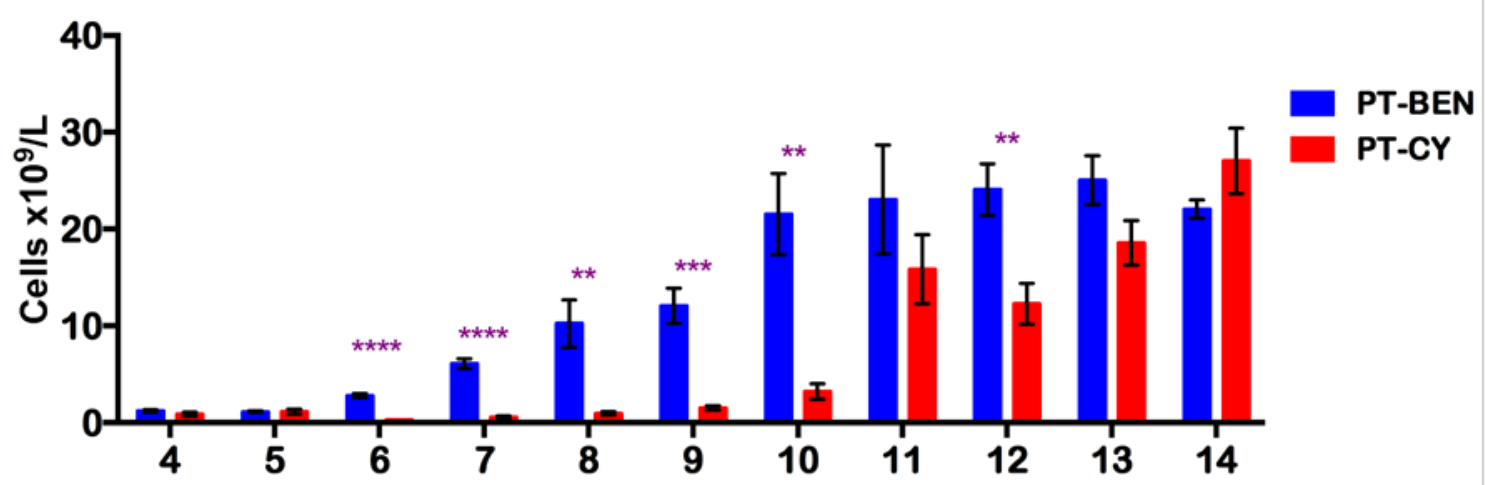

B

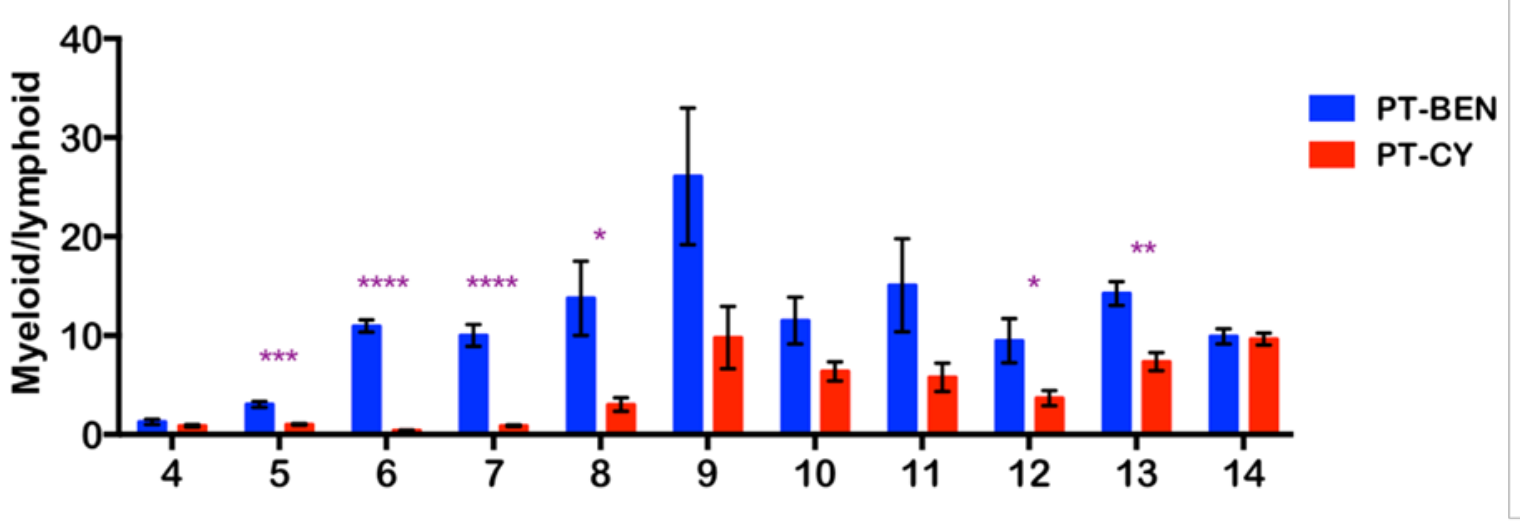

C

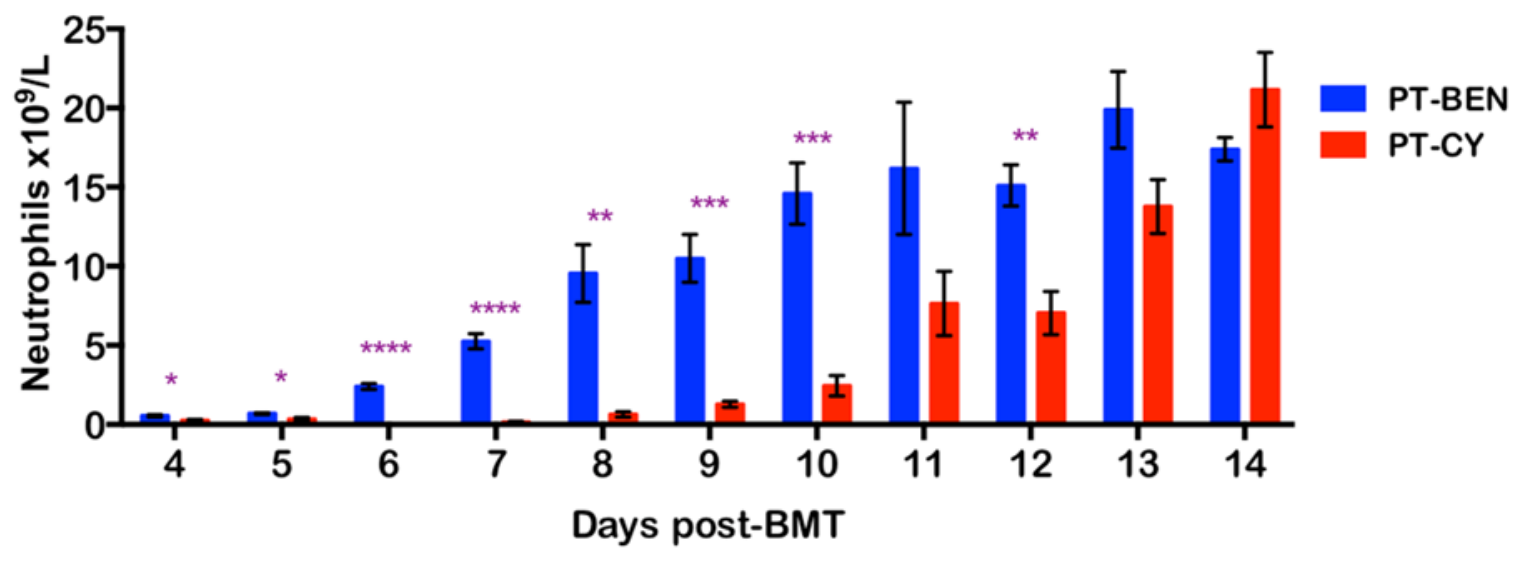


1 Supplemental Figure 5: CAF1/J mice received MAC (A) or RIC (B) TBI on day -1 and $h-$

$2 \mathrm{BMT} / \mathrm{SC}$ from CB6F1 mice on day 0. PT-BEN $30 \mathrm{mg} / \mathrm{kg}$ was given on day +3 and PT-CY 75

$3 \mathrm{mg} / \mathrm{kg}$ was given on days +3 and +4 . Peripheral blood was collected on the indicated days by 4 tail tipping. Quantification of platelets, hemoglobin and red blood cells are shown with SEM.

5 Blood was analyzed using a HemaVet blood counter. MAC $n=4-12$ mice/group, RIC $n=8$ 6 mice/group (pooled data from 2-3 experiments). Significance was determined by Mann-Whitney 7 tests. ${ }^{*}=P<.05,{ }^{* *}=P<.01,{ }^{* *}=P<.001$.

A
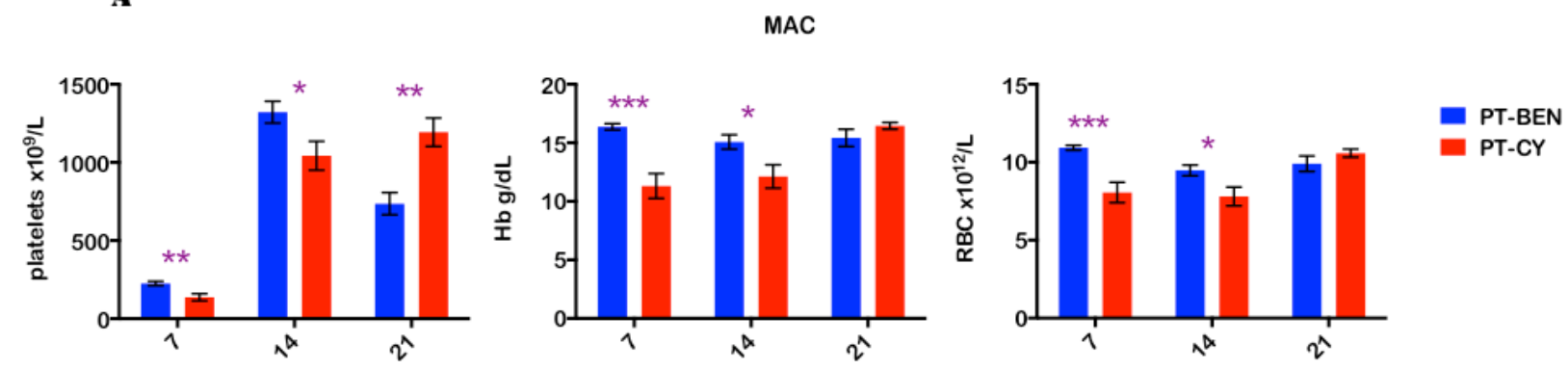

B

RIC
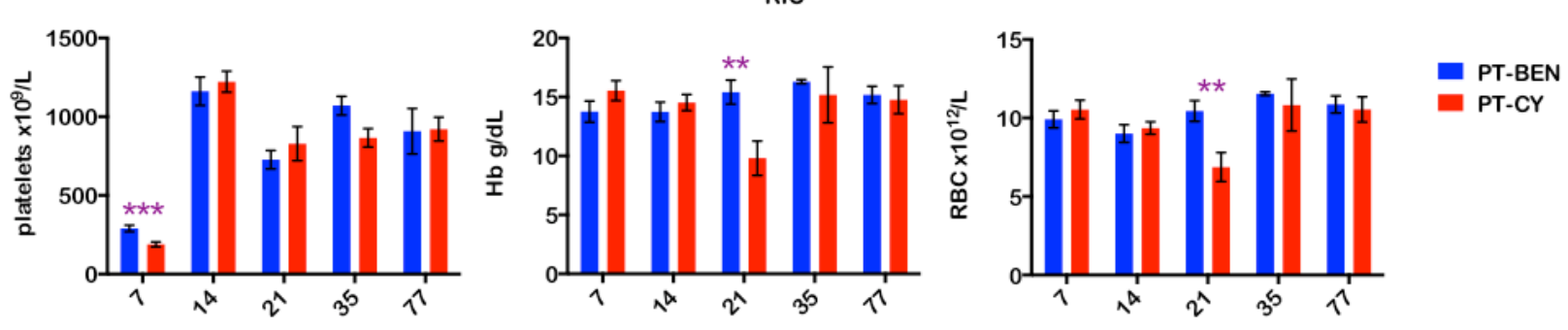

Days post-BMT 
1 Supplemental Figure 6: CAF1/J mice received RIC TBI, h-BMT/SC from CB6F1 mice and PT-

2 BEN $30 \mathrm{mg} / \mathrm{kg}$ on day +3 . On days +10 and +14 , mice were euthanized and blood and spleen

3 were collected. Gr-1 ${ }^{\text {hi }}$ cells were isolated and co-cultured at a 1 to 1 ratio with stimulated,

4 CellTrace stained total T-cells from naïve CB6F1 spleens for 3 days to determine their

5 suppressive function. The solid gray shows stimulated T-cells alone. The blue line shows

6 stimulated T-cells co-cultured with isolated Gr- $1^{\text {hi }}$ cells. Representative of two experiments.

Day 10
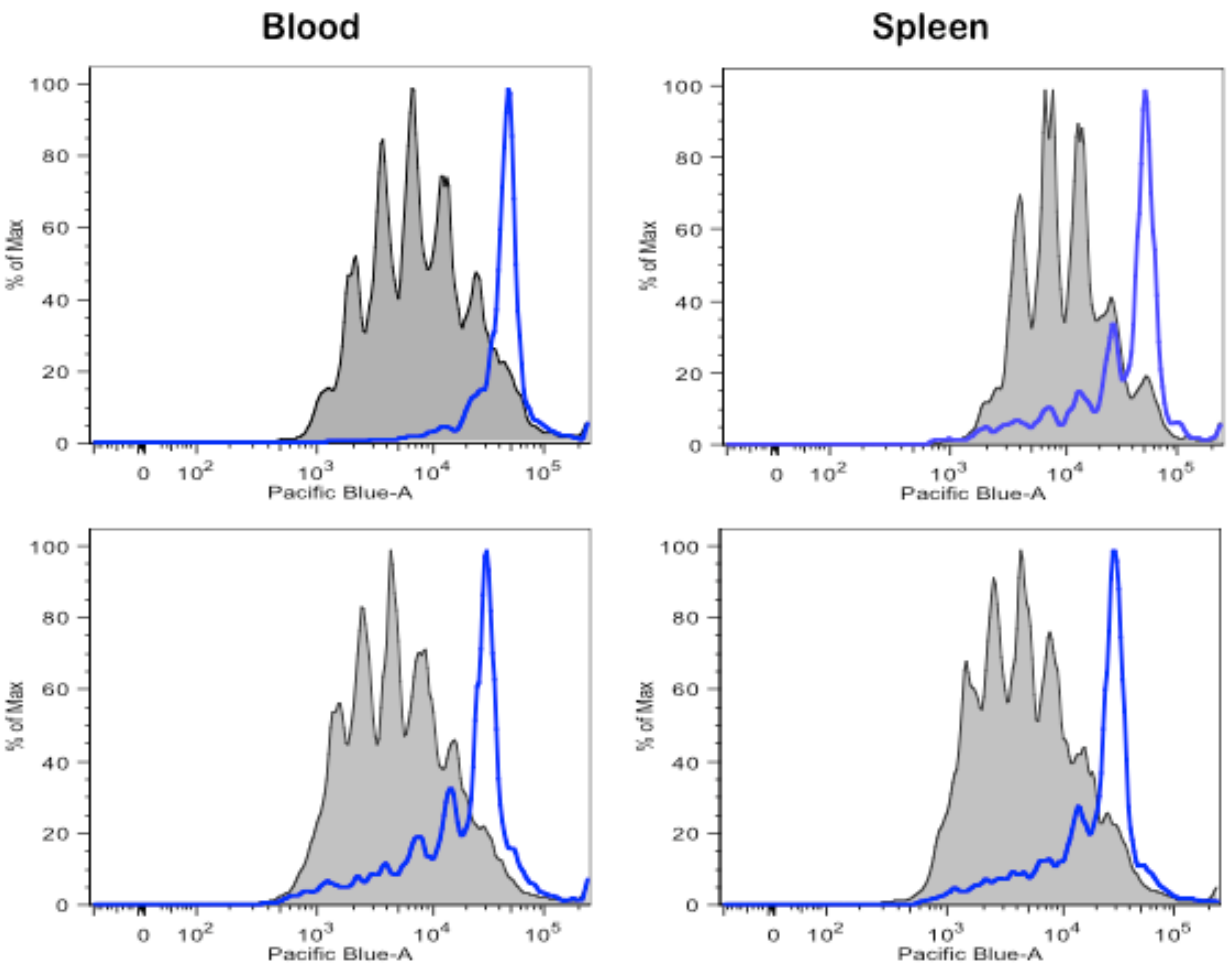

Day 14 
1 Supplemental Figure 7: MDSCs were generated using BM cells from naïve CB6F1 mice. BM 2 cells were cultured for 3 days with $10 \mathrm{ng} / \mathrm{mL}$ murine IL-6, murine GM-CSF and human G-CSF 3 and various concentrations of BEN (0-100 $\mu \mathrm{M})$. Cells were then phenotyped by flow cytometry. 4 Gating strategy and representative data is shown.

5
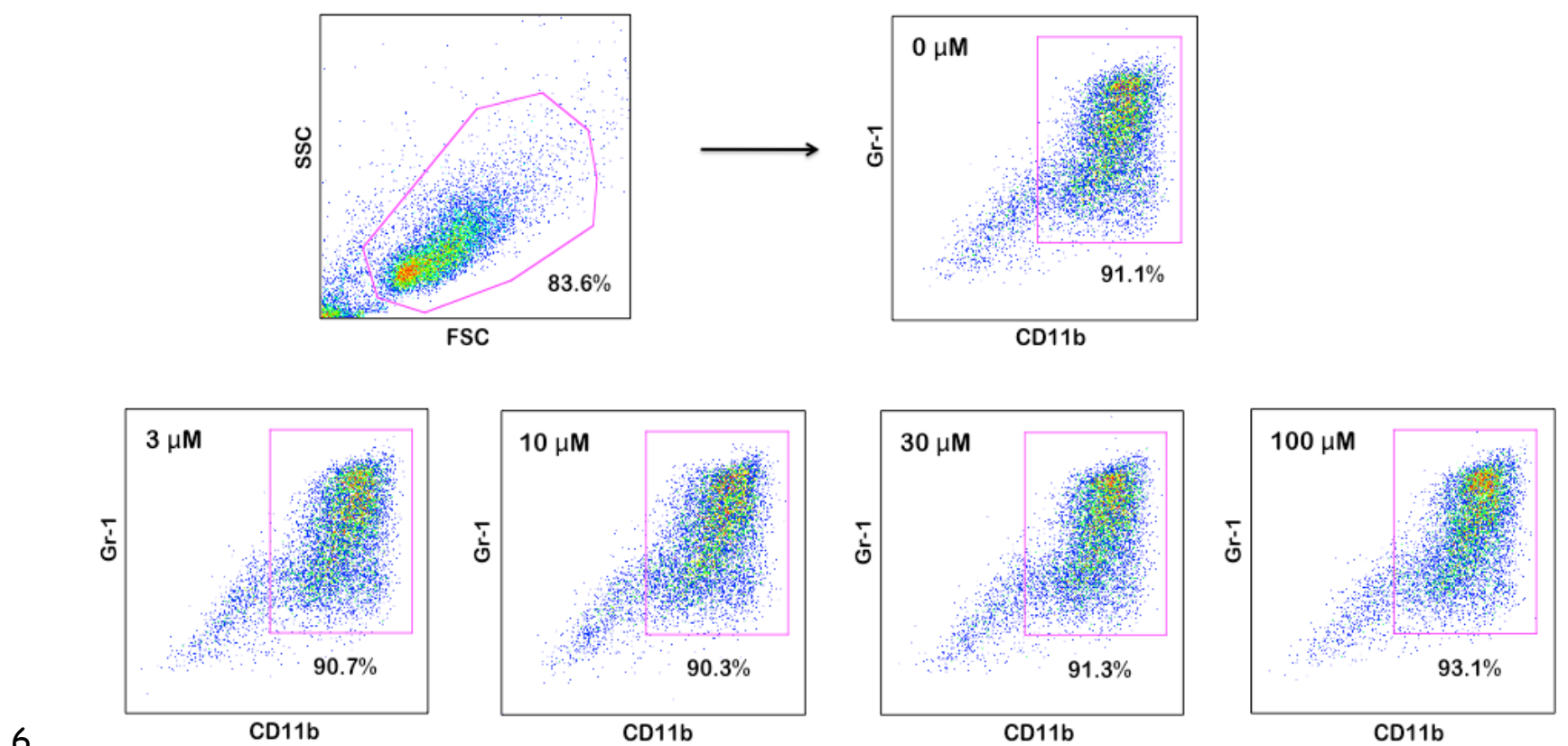
1 Supplemental Figure 8: CAF1/J mice received MAC or RIC TBI on day -1 and T-cell depleted 2 h-BMT or h-BMT/SC $\left(30 \times 10^{6}\right.$ or $\left.3 \times 10^{6}\right)$ from CB6F1 mice on day 0. PT-BEN (30 mg/kg) or CY 3 (150 mg/kg) was given on day +3 and $1 \times 10^{5}$ A20-Luc cells were injected i.v day +4 . Survival 4 from tumor (A, B) is shown. Kaplan-Meier survival curves were generated and analyzed using 5 the log-rank test. MAC: (A) $h-B M T / S C+P T-B E N$ or $P T-C Y$ vs $h-B M T P<.01$. $h-B M T / S C+P T-$ $6 B E N$ vs $h-B M T / S C+P T-C Y \quad P=n s$. (B) $h-B M T / S C+P T-B E N$ or $P T-C Y$ vs $h-B M T P<.01$. $h-$ $7 \quad B M T / S C+P T-B E N$ vs $h-B M T / S C+P T-C Y P<.05$. RIC: (A) $h-B M T / S C+P T-B E N$ vs $h-B M T P<.01$. $8 h-B M T / S C+P T-C Y$ vs $h-B M T P=n s$. $h-B M T / S C+P T-B E N$ vs $h-B M T / S C+P T-C Y P=.002$. (B) $h-$ $9 B M T / S C+P T-B E N$ vs $h-B M T P=n s$. $h-B M T / S C+P T-C Y$ vs $h-B M T P<.01 . h-B M T / S C+P T-B E N$ vs $10 \quad h-B M T / S C+P T-C Y P<.01$.

11

A

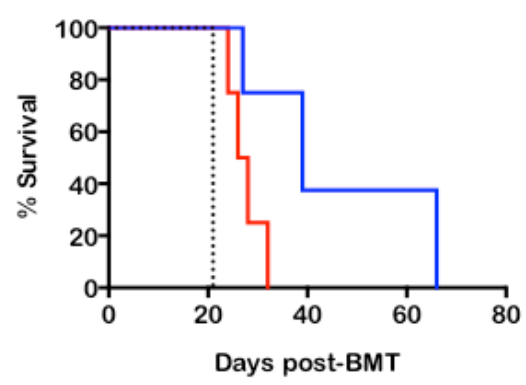

B

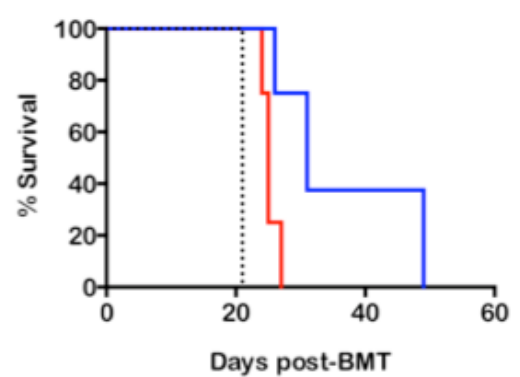

RIC $30 \times 10^{6} \mathrm{SC}$ - Tumor Survival

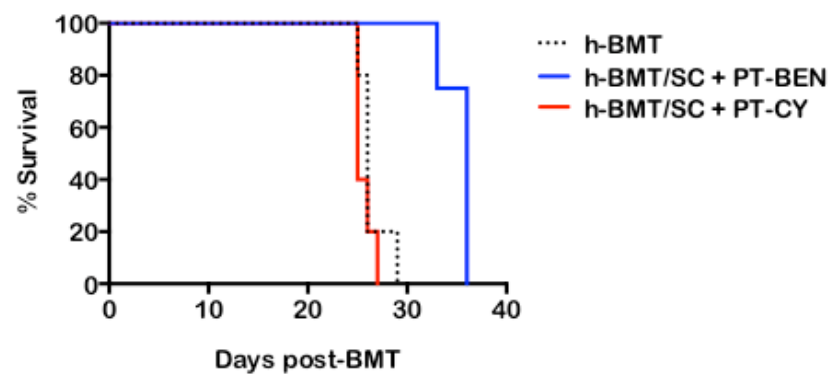
$3 \times 10^{6}$ SC- Tumor Survival

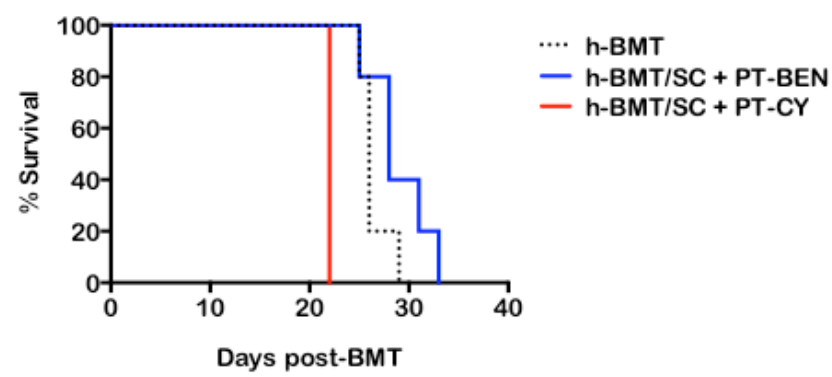

